\title{
Article \\ Effect of By-Products from Selected Fruits and Vegetables on Gluten-Free Dough Rheology and Bread Properties
}

\author{
Fairouz Djeghim ${ }^{1}(\mathbb{D})$, Hayat Bourekoua ${ }^{1}\left(\mathbb{D}\right.$, Renata Różyło ${ }^{2, *} \mathbb{D}$, Agata Bieńczak ${ }^{3}$, Wojciech Tanaś ${ }^{4}$ \\ and Mohammed Nesreddine Zidoune ${ }^{1}$
}

1 Equipe de Transformation et Elaboration de Produits Agro-alimentaires (TEPA), Laboratoire de Nutrition et Technologie Alimentaire (LNTA), Institut de la Nutrition, de l'Alimentation et des Technologies Agro-Alimentaires (INATAA), Université Frères Mentouri-Constantine 1, Route de Ain El-Bey, 25000 Constantine, Algeria; fairouzdje@live.fr (F.D.); bourekoua.hayat@umc.edu.dz (H.B.); zidounem@yahoo.fr (M.N.Z.)

2 Department of Food Engineering and Machines, University of Life Sciences in Lublin, 28 Głçboka Str., 20-612 Lublin, Poland

3 Department of Foodstuff Technics and Technology, Łukasiewicz Research Network - Industrial Institute of Agricultural Engineering, 31 Starołęcka Str., 60-963 Poznań, Poland; agata.bienczak@pimr.lukasiewicz.gov.pl

4 Department of Agricultural Forestry and Transport Machines, University of Life Sciences in Lublin, 28 Głçboka Str., 20-612 Lublin, Poland; wojciech.tanas@up.lublin.pl

* Correspondence: renata.rozylo@up.lublin.pl

Citation: Djeghim, F.; Bourekoua, H.; Różyło, R.; Bieńczak, A.; Tanaś, W.; Zidoune, M.N. Effect of By-Products from Selected Fruits and Vegetables on Gluten-Free Dough Rheology and Bread Properties. Appl. Sci. 2021, 11, 4605. https://doi.org/10.3390/ app11104605

Academic Editor: Silvia Mironeasa

Received: 18 April 2021

Accepted: 12 May 2021

Published: 18 May 2021

Publisher's Note: MDPI stays neutral with regard to jurisdictional claims in published maps and institutional affiliations.

Copyright: (c) 2021 by the authors. Licensee MDPI, Basel, Switzerland. This article is an open access article distributed under the terms and conditions of the Creative Commons Attribution (CC BY) license (https:// creativecommons.org/licenses/by/ $4.0 /)$.
Abstract: The aim of the study was to investigate the effect of using various by-products (orange and apple pomace, tomato peel, pepper peel, prickly pear peel, and prickly pear seed peel) on the dough rheology and properties of gluten-free bread. The by-products were incorporated into a gluten-free bread formulation based on corn and chickpea flours $(2 / 1 w / w)$. Different levels of each by-product $(0,2.5,5$, and $7.5 \%$ in the basic replacement) were tested. Wheat bread and gluten-free bread without the addition of by-products were used as controls. The results indicated that the by-products increased the maximum dough height, the total $\mathrm{CO}_{2}$ production, and $\mathrm{CO}_{2}$ retention coefficient compared to unenriched gluten-free dough. The highest K-value consistency coefficient was observed for the dough enriched with the prickly pear peel. The addition of by-products significantly improved $(p<0.0001)$ the specific volume of gluten-free bread, with values increasing from 1.48 to $2.50 \mathrm{~cm}^{3} / \mathrm{g}$. The hierarchical cluster analysis and the constellation plot showed four groups: the wheat bread group, the second group containing the gluten-free control bread, the group with bread enriched by pomace, and the group with bread enriched with peels, exhibit the same effect on gluten-free bread and the peels exhibit the same effect on gluten-free bread.

Keywords: gluten-free bread; pomace; peel; rheology; bread properties

\section{Introduction}

Global market data have shown $10.4 \%$ compound annual growth rate in gluten-free sales between 2015 and 2020 because of the incidence of celiac disease and other glutenassociated allergies [1,2]. The gluten-free market today provides a variety of foods that can be eaten safely by patients suffering from celiac disease [3]. Bread is one of the major staple foods $[4,5]$. In general, breads formulated with gluten-free raw materials have low nutritional properties, poor taste, and are of inferior quality. In the absence of gluten, dough presents poor rheological properties (viscoelasticity) and is unable to develop a protein network, affecting the final quality of gluten-free bread [6,7].

The replacement of gluten is one of the most challenging problems in food technology [8]. The use of alternative ingredients including starch, hydrocolloids, protein, enzymes, emulsifiers, and fibers in the preparation of gluten-free bread can improve the texture, mouthfeel, acceptability, shelf life, and nutritional properties of the products. In 
addition, the viscoelastic properties of gluten can be imitated [9-12]. Similar effects can be expected when adding fruit and vegetable by-products to bread [13].

Some by-products from fruit and vegetable processing are appropriate sources of nutrients and functional ingredients for gluten-free products, and could be used as lowcost ingredients. Fruit and vegetable by-product processing includes pomace, peel, and seed fractions, which are good sources of functional substances. These products offer beneficial bioactive compounds such as carotenoids, enzymes, polyphenols, oils, vitamins, dietary fibers, amino acids, and proteins for gluten-free products [14-16]. Dried fruit pomace can be used in bakery products to substitute flour, sugar, or fat, increasing the amount of fiber and antioxidants and reducing the energy consumption [8]. Each fruit and vegetable contains approximately $5-50 \%$ of peel/skin by-products, which are rich in cellulose, hemicellulose, and lignin as major constituents and may also contain other functional groups of lignin, including aldehydes, ketones, alcohols, carboxyl, hydroxide, and phenols [17]. In addition, antioxidant components, flavonoids, minerals, and vitamins are also available in such by-products [18-20].

Many studies are in progress to evaluate the effects of fruit and vegetable by-products (such as orange peel, pomegranate peel, mango peel, grape peel, and potato peel) on wheat bread to improve the texture and quality of the final products [21-23], but only a few studies have been conducted on the utilization of fruit and vegetable peels for gluten-free bread products.

Thus, in this study we evaluated the rheological and gluten-free properties of bread prepared with corn and chickpea flours and enriched with two different types of pomace (from orange and apple) and four different types of peels (from tomato, pepper, prickly pear, and prickly pear seeds). These breads were compared with the non-enriched gluten-free bread and wheat bread.

\section{Materials and Methods}

\subsection{Breadmaking Materials}

Soft white wheat flour was obtained from Kenza (Constantine, Algeria), and contained $12.01 \%$ moisture, $0.52 \%$ ash, $2.08 \%$ fat, $7.9 \%$ protein content, $77.04 \%$ carbohydrates, and $0.45 \%$ fiber. Corn flour (Bio Aglut, Constantine, Algeria) had $9.96 \%$ moisture, $0.83 \%$ ash, $1.8 \%$ fat, $7.9 \%$ protein content, $76.31 \%$ carbohydrates, and $3.2 \%$ fiber. Chickpea flour $(9.22 \%$ moisture, $2.67 \%$ ash, $4.35 \%$ fat, $22 \%$ protein content, $58.33 \%$ carbohydrates and $3.43 \%$ fiber) was obtained after grinding dried chickpea grains provided by CCLS (Constantine, Algeria). Salt (ENAsel, Setif, Algeria) and instant dry yeast (Saf-instant, Maisons-Alfort, France) were purchased from a local market.

\subsection{By-Product Materials}

The raw materials for the research were by-products of selected fruits and vegetables including oranges (Citrus sinensis), apples (Malus domestica), tomatoes (Solanum lycopersicum), peppers (Capsicum annum), and prickly pears (Opuntia ficus-indica). These by-products were sourced from Algerian food industries.

The orange pomace (peel, a small amount of pulp and seeds) was obtained after juice extraction from N'Gaous-Conserves (SPA, Batna, Algeria).

Apple, tomato, and pepper pomace were collected from Maison Latina (Chelghoum Laid-Mila, Algeria). Apple pomace (peel, a small amount of pulp, and seeds) came from the processing of apple jam. Tomato pomace (peels and seeds) was derived from the production of tomato paste. The paprika pomace from green sweet pepper and red-hot pepper (peels and seeds) was obtained after the preparation of Hmiss (a local Algerian product).

The dried peel of prickly pear seeds was formed during a process of separating the prickly pear seeds from the pulp (Figure 1), which was supplied by Nopaltec (Souk Ahras, Algeria). Fresh, ripe red-yellow prickly pear fruits were harvested from private farms (Ain beïda Ahriche, Mila, Algeria). 


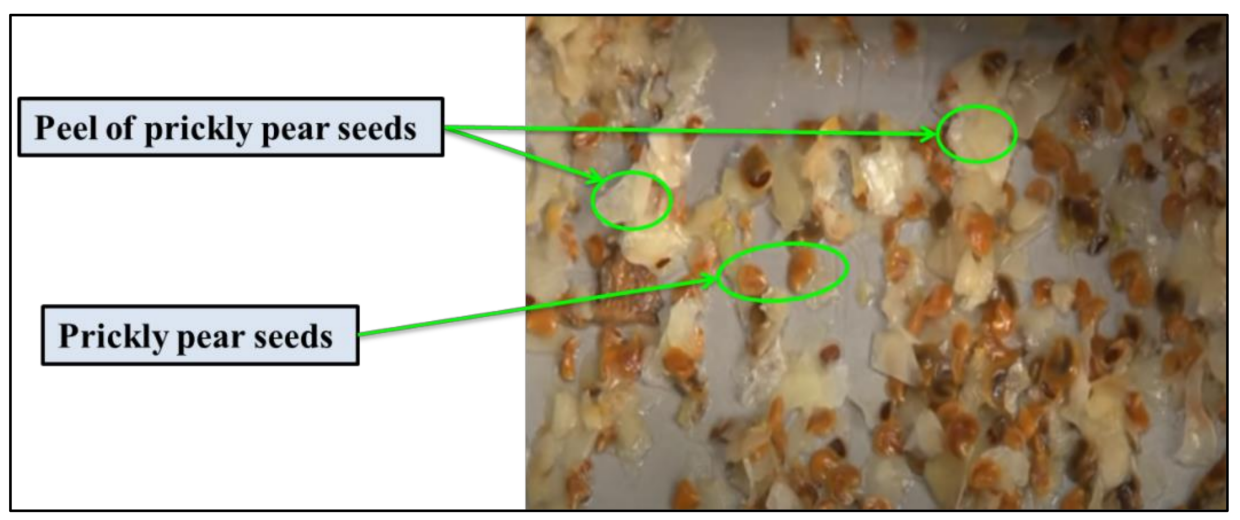

Figure 1. Seeds and seed peels of prickly pear during the processing of separation.

\subsubsection{Preparation of By-Product Samples}

The orange and apple by-products were dried at $40{ }^{\circ} \mathrm{C}$ in a ventilated dryer (MAXEI, S.A. ARRAS MAXEI, Type MC 100, Arras, France). Then, the dried pomace was manually separated from the seeds. The tomato and pepper by-products were dried at $40{ }^{\circ} \mathrm{C}$ in a fluid bed dryer (Retsch. TG 200, Haan, Germany). Then, the seeds were separated from the pomace by sieving $(1100 \mu \mathrm{m})$.

The prickly pear fruits were washed several times using distilled water to remove the thorns, placed on a sieve to drain out surface water, and manually peeled with a knife. The obtained peel ( $46.60 \pm 2.40 \%$ of peel) was cut into small pieces, and then the samples were dried in the ventilated dryer at $35^{\circ} \mathrm{C}$. The peel of prickly pear seeds donated by the food industry was already dried. The weight percent of each by-product fraction is shown in Table 1.

Table 1. The proportion of pulp, peel, and seeds in selected fruit and vegetable by-products.

\begin{tabular}{|c|c|c|}
\hline Product & By-Product & Waste Content (\%) \\
\hline \multirow{2}{*}{ Orange * } & Peel + pulp & 94.50 \\
\hline & Seeds & 5.50 \\
\hline \multirow{2}{*}{ Apple * } & Peel + pulp & 91.22 \\
\hline & Seeds & 8.78 \\
\hline \multirow{2}{*}{ Tomato * } & Peel & 52.13 \\
\hline & Seeds & 47.87 \\
\hline \multirow{2}{*}{ Pepper * } & Peel & 61.5 \\
\hline & Seeds & 38.50 \\
\hline \multirow{2}{*}{ Prickly pear ** } & Peel & 46.60 \\
\hline & Seeds + pulp & 53.40 \\
\hline
\end{tabular}

* Dried pomace. ${ }^{* *}$ Fresh pomace.

All dried seedless by-product samples (Figure 2) including dried orange pomace (DOP), dried apple pomace (DAP), dried pepper peel (DPP), dried tomato peel (DTP), dried prickly pear peel (DPPP), and dried prickly pear seed peel (DPPSP) were milled to a particle size of $500 \mu \mathrm{m}$. The by-product powders were stored at room temperature $\left(25 \pm 5{ }^{\circ} \mathrm{C}\right)$ until further use.

\subsubsection{Physico-Chemical Analysis of By-Product Samples}

\section{Proximate Composition}

The moisture, ash, fat, and protein contents of the by-product powders (pomace and peels) were determined by the standard AOAC method [24]. The moisture content was determined by AOAC method 926.12, the ash content by the AOAC method 942.05, and the protein content by the AOAC method 960.52 . The fiber content was determined according 
to the Weende method [25] using a raw fiber extractor. The total carbohydrates were calculated by subtracting: $100-(\%$ water $+\%$ ash $+\%$ total fat $+\%$ total protein $+\%$ total fiber). The chemical composition was determined 3 times.

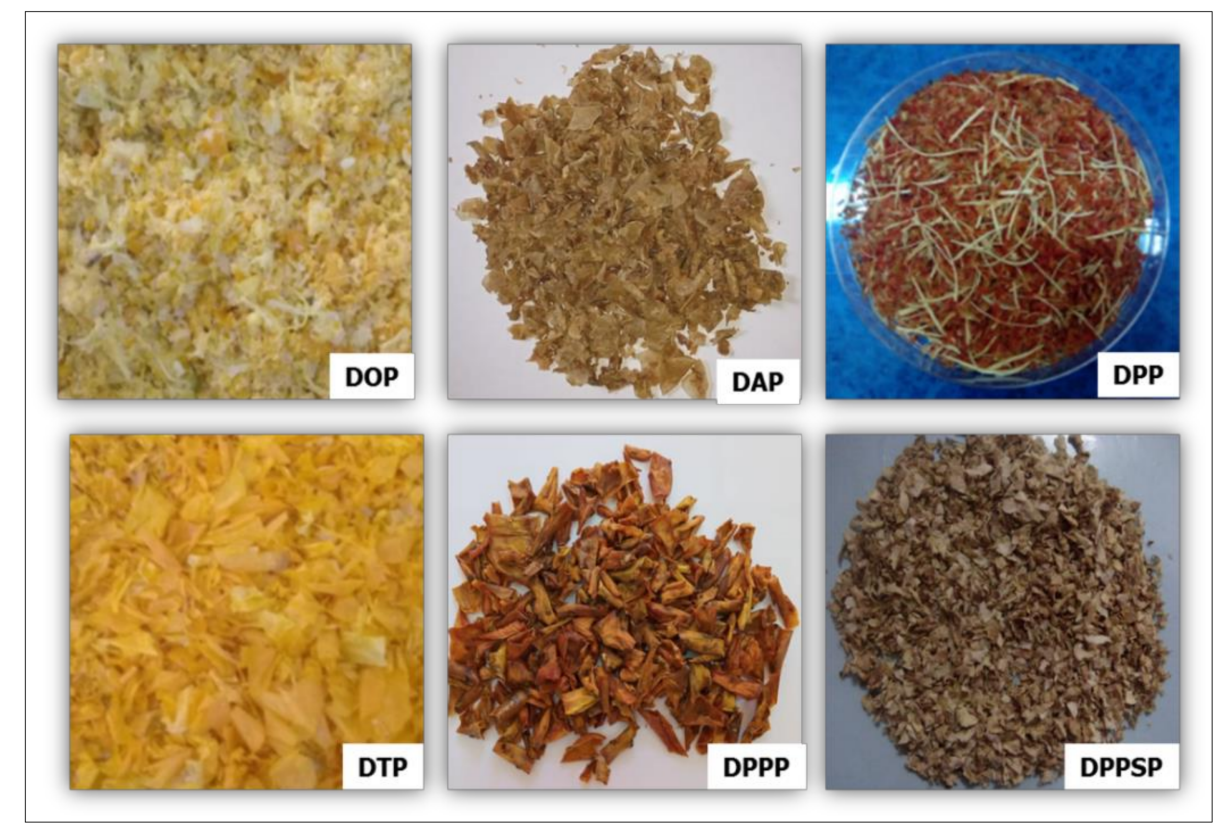

Figure 2. Dried fruit and vegetable by-product samples. DOP: dried orange pomace; DAP: dried apple pomace; DPP: dried pepper peel; DTP: dried tomato peel; DPPP: dried prickly pear peel; DPPSP: dried prickly pear seed peel.

Extraction of Pectins from By-Product Samples

Extraction was carried out on powders from dried pomace and peels. Each sample $(2 \mathrm{~g})$ was mixed with $40 \mathrm{~mL}$ of hydrochloric acid $(0.1 \mathrm{~N})$, heated at $90^{\circ} \mathrm{C}$ for $45 \mathrm{~min}$, and then cooled to room temperature. The insoluble material was then removed by filtration through a nylon strainer. The filtrate was dispersed in 2 volumes of ethanol $95 \%(\mathrm{~V} / \mathrm{V})$; pectin was precipitated overnight at room temperature away from light. The precipitate was collected by filtration through a nylon strainer, washed twice with 70\% ethanol, and centrifuged $\left(20 \mathrm{~min} ; 10,000 \mathrm{tr} / \mathrm{min}, 10^{\circ} \mathrm{C}\right)$. The supernatant was then discarded and the obtained wet pectin was dried at $65^{\circ} \mathrm{C}$ until constant weight [26-28]. The percentage yield of pectin samples was calculated as follows [29]:

$$
\text { Pectin yield }(\%)=\frac{\text { Obtained product }}{\text { Initial by product powder }} \times 100
$$

\section{Water-Holding Capacity}

The water-holding capacity was calculated as the water weight which is retained by $1 \mathrm{~g}$ of dry by-product sample after soaking and centrifugation [30]. The water-holding capacity (WHC) of samples was determined by mixing $1 \mathrm{~g}$ of by-product powder with $15 \mathrm{~mL}$ of distilled water in a centrifuge tube. The mixture was vortexed (VELP Scientifica, $\mathrm{ZX}^{3}$ ) for $30 \mathrm{~s}$ and allowed to hydrate overnight. The suspension was then centrifuged (Sigma 3-30K, Osterode am Harz, Germany) at 15,000 $\times g$ for $20 \mathrm{~min}$. The supernatant was discarded, and WHC was expressed as gram water retention per gram dry powder [31,32].

\subsection{Characteriscics of the Bread Dough}

The wheat control dough was made from wheat flour and without by-products. The gluten-free control dough was made with corn flour and chickpea flour, also without by-products. The fortified gluten-free doughs were prepared by adding by-products at 
different levels $(2.5,5$, and $7,5 \% w / w)$. Doughs were prepared according the same process of breadmaking. Then, the properties of the dough were examined with the help of Chopin's rheofermentometer and a rheoviscosimeter.

\subsubsection{Rheofermentometric Analysis}

A Chopin rheofermentometer (F3 Chopin, Villeneuve La Garenne Cedex, France) was used to measure the gas production and dough development parameters during the fermentation process. A piece of dough $(200 \mathrm{~g})$, prepared as described in the breadmaking process, was placed in the rheofermentometer basket, and the piston was placed on dough without the $2 \mathrm{~kg}$ of cylindrical weight for gluten-free dough [33-35]. The dough was then fermented for $90 \mathrm{~min}$ at $37^{\circ} \mathrm{C}$. The recorded parameters were: Maximum height of dough $\left(\mathrm{H}_{\mathrm{m}}\right)$, time at a maximum height of dough $\left(\mathrm{T}_{1}\right)$, maximum height of gaseous release $\left(\mathrm{H}_{\mathrm{m}}^{\prime}\right)$, time of maximum gas formation $\left(\mathrm{T}^{\prime}{ }_{1}\right)$, height of dough at the end of the test $(\mathrm{h})$, weakening coefficient $(\mathrm{W})=\left(\mathrm{H}_{\mathrm{m}}-\mathrm{h}\right) / \mathrm{H}_{\mathrm{m}}$, total $\mathrm{CO}_{2}$ production $\left(\mathrm{V}_{\mathrm{t}}\right)$, volume of $\mathrm{CO}_{2}$ loss $\left(\mathrm{V}_{1}\right)$, volume of $\mathrm{CO}_{2}$ retained $\left(\mathrm{V}_{\mathrm{r}}\right)$, and $\mathrm{CO}_{2}$ retention coefficient $(\mathrm{R})$. The analyses were performed in duplicate.

Moreover, to isolate the effect of yeast activity, the adjusted maximum height $\left(H_{m}{ }^{\text {adj }}\right)$ was calculated according to the method of Altuna and Ribotta [36].

$$
H_{m}^{a d j}=\left(\frac{H_{m}}{V_{t}}\right) \times V_{t 0}
$$

where $V_{t 0}$ is the total volume of the gas obtained from the control dough.

\subsubsection{Rheological Measurements of Dough (Flow Test)}

The flow test of dough was measured with a rheoviscosimeter. All dough ingredients except the yeast were mixed with an overhead mixer (Heidolph RZR 2020, Schwabach, Germany) at $210 \mathrm{rpm}$. The dough was then left for $20 \mathrm{~min}$ before being placed in a Haake VT 550 rheometer (Haake MessTechnik Gmbh Co, Karlsruhe, Germany) to release the residual stress. The dough samples were placed on a parallel plate geometry, the plate diameter was $50 \mathrm{~mm}$ (Haake, PK 5, 0.5 grads), and the gaps between the plates were of $4.5 \mathrm{~mm}$. Fine-grained sandpaper was glued to the top and bottom plates to limit possible slippage between the plates and the dough [37-39]. The excess dough was trimmed and the edges coated with paraffin oil to prevent dehydration of the sample. The dough was left for $5 \mathrm{~min}$ before starting the test to ease the stress and stabilize the temperature [40]. The temperature was maintained at $25^{\circ} \mathrm{C}$ by circulating water and the rheological data were analyzed with HAAKE Rheo Win software version 2.09 over a shear rate range of $1.2-200 \mathrm{~s}^{-1}$ for $3 \mathrm{~min}$. The number of measuring points was 100; each test was performed in triplicate. The apparent viscosity was determined using the low power law model (Ostwald de Waele) [35,41]:

$$
\eta_{a p}=K \cdot \gamma^{n-1}
$$

where $\eta_{a p}$ : apparent viscosity (Pa.s); $\gamma$ : shear rate $\left(\mathrm{s}^{-1}\right)$; and $n$ : flow behavior index. $K$ (consistency index, Pa.s ${ }^{\mathrm{n}}$ ) represents the stress required to obtain a shear rate of $1 \mathrm{~s}^{-1}$.

\subsection{Bread-Making Process}

\subsubsection{Pre-Hydration of By-Products}

By-product powders were soaked in distilled water overnight at room temperature. The amount of soaking in water required for this differed depending on the results of the water-holding capacity for each sample (Table 2). According to Chen and Rubenthaler [42], pre-hydration of the by-product reduces the absorption of water necessary to form the dough and reduces the water competition between the dough ingredients and the dry by-product. 
Table 2. Formulations of wheat and gluten-free bread.

\begin{tabular}{|c|c|c|c|c|c|}
\hline & $\begin{array}{l}\text { Wheat } \\
\text { CTRL1 }\end{array}$ & $\begin{array}{c}\text { GF } \\
\text { CTRL } 2\end{array}$ & $\begin{array}{c}2.5 \% \\
\text { B-P }\end{array}$ & $\begin{array}{l}5 \% \\
\text { B-P }\end{array}$ & $\begin{array}{l}7.5 \% \\
\text { B-P }\end{array}$ \\
\hline Wheat flour (g) & 100 & 0 & 0 & 0 & 0 \\
\hline Corn $(g)$ & 0 & 66.67 & 65 & 63.33 & 61.67 \\
\hline Chickpea flour (g) & 0 & 33.33 & 32.5 & 31.67 & 30.83 \\
\hline $\begin{array}{l}\text { DOP/ DAP/ DPP/ DTP/ } \\
\text { DPPP/DPPSP (g) }\end{array}$ & 0 & 0 & 2.5 & 5 & 7.5 \\
\hline Water for dough (mL) & 63.25 & 100 & 97.5 & 95 & 92.5 \\
\hline $\begin{array}{l}\text { Water for pre-hydration } \\
\qquad(\mathrm{mL})\end{array}$ & 0 & 0 & $2.5 \times X$ & $5 \times X$ & $7.5 \times X$ \\
\hline Salt(g) & 2 & 2 & 2 & 2 & 2 \\
\hline Yeast (g) & 2 & 2 & 2 & 2 & 2 \\
\hline
\end{tabular}

CTRL: control; DOP: dried orange pomace; DAP: dried apple pomace; DTP: dried tomato peel; DPP: dried pepper peel; DPPP: dried prickly pear peel; DPPSP: dried prickly pear seed peel; B-P: by-product; X: water-holding capacity (WHC).

\subsubsection{Preparation of Bread}

Bread with $100 \mathrm{~g}$ of wheat flour was prepared as control of wheat bread (Wheat CTRL 1). Gluten-free bread made from a mixture of corn flour and chickpea flour at a ratio of $2 / 1(w / w)$ and with $0 \% w / w$ addition of by-products represented the gluten-free control bread (GF CTRL 2). Gluten-free breads were prepared and enriched with pomace and peel powders.

Gluten-free bread recipes were prepared by replacing the base flour with $0,2.5,5$, or $7.5 \%(w / w)$ by-products (DOP, DAP, DPP, DTP, DPPP, or DPPSP). All by-product powders were used after their pre-hydration. The flour, yeast, by-products, and water were mixed for $1 \mathrm{~min}$ at medium speed. Then salt, previously dissolved in water, was gradually added to the mixture. The dough was mixed for an additional $6 \mathrm{~min}$; then, the obtained dough was divided, molded, placed in an aluminum foil pan $(9 \times 7 \times 3 \mathrm{~cm})$, and fermented at $37^{\circ} \mathrm{C}$. The fermentation time varied depending on the $\mathrm{T}_{1}$-the time at which dough attains the maximum height $\left(\mathrm{H}_{\mathrm{m}}\right)$ in rheofermentometer measurements. The baking test was carried out in an aluminum foil pan in an electric oven at $230{ }^{\circ} \mathrm{C}$ for $30 \mathrm{~min}$. After baking, the bread was cooled at room temperature. The wheat control bread was prepared without any additives, as was the gluten-free control bread. The formulations for each type of bread are presented in Table 2.

\subsection{Bread Quality Evaluation}

The analysis of wheat and gluten-free bread was performed after $1 \mathrm{~h}$ of baking and included: weight loss, specific volume, moisture content, $\mathrm{pH}$ of bread, color, and crumb cell analysis.

Weight loss $(W L)$ is the difference between the weight of the dough and the weight of the bread just after baking dividing by the weight of dough [43].

\subsubsection{Specific Volume}

The loaf volume was calculated by the rapeseed displacement method (10.05) [44], and the specific volume $\left(\mathrm{cm}^{3} / \mathrm{g}\right)$ was calculated by dividing the volume by the weight.

\subsubsection{Moisture Content}

Moisture content in bread was determined according to the ICC 110/1 method [45].

\subsubsection{Measurement of $\mathrm{pH}$ Values}

The bread was ground into a fine powder; $10 \mathrm{~g}$ of this powder was mixed with $100 \mathrm{~mL}$ of distilled water which had an initial $\mathrm{pH}$ of $5.68 \pm 0.16$. The mixture was then placed on an orbital shaker (Heidolph polymax 1040, Schwabach, Germany) and stirred for $30 \mathrm{~min}$ at 
room temperature. The $\mathrm{pH}$ was measured in the supernatant solution after a resting time of $10 \mathrm{~min}[46,47]$.

\subsubsection{Color Analysis}

The color of the crust and the crumb of the bread were determined according to the method of He and Pei [48] using the Color Grab color-extracting application (version 3.6.1, 2017, Loomatix Ltd., Munchen, Germany). To ensure that the color capture was not affected by ambient light, a closed polystyrene box $(39 \times 17 \times 28 \mathrm{~cm})$ was used, integrated with a $1.2 \mathrm{~W} 5 \mathrm{~V}$ white LED to obtain an evenly scattered light on top of the sample. The CIE- $L^{*} a^{*} b^{*}$ color space mode was chosen. This is a mathematical color model based on the sensitivity of the human visual spectrum [49], where $L^{*}$ represents the lightness, $a^{*}$ represents green $/$ red + , and $b^{*}$ represents blue $-/$ yellow + . Color measurements were taken at 5 different locations on the same crust or crumb.

\subsubsection{Crumb Cell Analysis}

Image processing was performed using the Image J software (1.43u; Java1.7.0-2132 bit, Wayne Rasband, National Institute of Mental Health (NIH), Bethesda, MD, USA). The bread was cut on a horizontally into 2 slices. The slice images were captured and saved in TIFF format. Each image was cropped to keep only the bread crumb and then converted to 8-bit grayscale to obtain black (crumb pores) and white (crumb) thresholds. The measured parameters were as follows: cell number $/ \mathrm{mm}^{2}$, average pore size, pore area fraction, perimeter, and solidity.

\subsection{Statistical Analysis}

Statistical analysis was performed using the statistical JMP Trial 15(SAS Institute Inc., Cary, NC, USA). The significance of the difference between the mean values was estimated using one-way analysis of variance (ANOVA), and the means were compared using the Tukey's test $(p \leq 0.05)$. Principal component analysis (PCA) and hierarchical cluster analysis (HCA) were carried out to establish the correlation between dough properties and bread quality. The HCA was based on the Ward method using Euclidean distances to show the similarities and differences between the bread samples. The by-product addition percentage parameter was excluded from the HCA. The results of PCA and HCA are presented in graphical form.

\section{Results and Discussion}

\subsection{Physicochemical Properties of By-Products \\ 3.1.1. Proximate Composition}

Table 3 shows the proximate composition of the by-products. The moisture content of the samples ranged from $5.23 \%$ to $11.41 \%$; protein content ranged from $2.66 \%$ to $8.48 \%$, fat from $1.03 \%$ to $4.37 \%$, and the fiber and ash contents ranged from $7.41 \%$ to $52.90 \%$ and from $1.51 \%$ to $19.60 \%$, respectively. Carbohydrate content ranged from $16.88 \%$ to $64.36 \%$. All the present by-products had a different composition $(p<0.05)$. The highest moisture content was found for DAP and the highest values of ash and protein content were noted for DPPP. These values are higher than those found by Anwar and Sallam [18]. When it comes to fat, DOP had a high value compared to other by-products. DTP, DPPSP, and DPP presented high fiber contents compared to other by-products (greater than $49 \%$ ). It was found that DAP was rich in carbohydrates; the proximate composition of DAP was confirmed by Skinner and Gigliotti [50]. Differences between the proximate composition of by-products obtained in this study and the results of other studies may be due to geographic location, season, variety, ripeness, or processing. 
Table 3. Physico-chemical characteristics of by-products (per $100 \mathrm{~g}$ ).

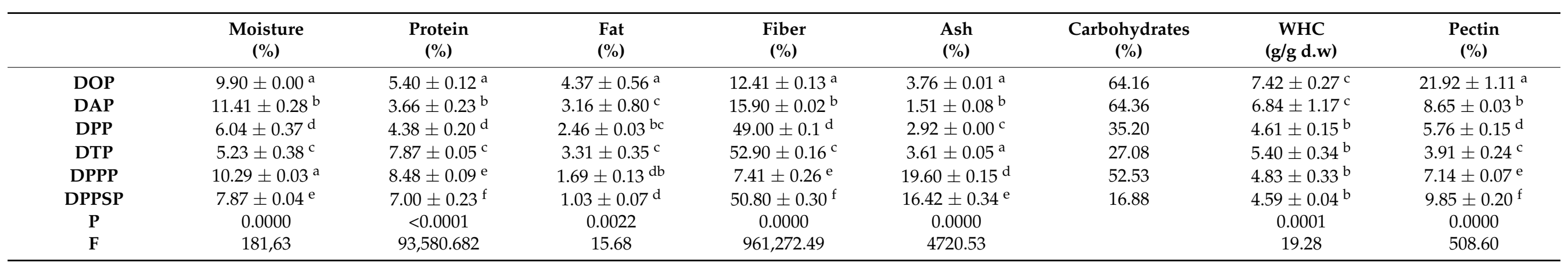

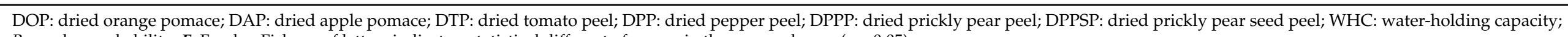
$P: p$-value probability; F: F-value Fisher. a-f letters indicate a statistical different of means in the same column. $(p<0.05)$. 


\subsubsection{Water-Holding Capacity}

As shown in Table 3, DOP presented the greatest water-holding capacity $(7.42 \mathrm{~g} / \mathrm{g}$ d.w), followed by DAP and DTP. There was no difference between the WHC of DTP, DPP, DPPP, and DPPSP.

The water-holding capacity of DOP was found to be higher than that reported by Ocen and $\mathrm{Xu}$ [51]. The water-holding capacity of DAP was previously demonstrated by Bchir and Rabetafika [52]. Various factors can affect the water-holding capacity of the powder, such as $\mathrm{pH}$, the presence of hydrophilic components such as fiber and free hydroxyl groups, and flour porosity [53-55]. The substances with high WHC can be used as a functional ingredient to promote beneficial health effects, reduce calories, and change the viscosity and texture of processed foods $[56,57]$.

\subsubsection{Pectin}

As shown in Table 3, DOP had the highest pectin content (21.92\%); a lower value was noted for DTP from 3.91\%. As reported by Wang and Chen [58] the citrus peel is rich in pectin. Similarly, Sundarraj and Ranganathan [59] showed that citrus peel and apple pomace are the main sources of pectin. The pectin content in DPPP is $9.856 \%$, which is a higher value than that obtained by Anwar and Sallam [18]; this difference may be due to the ripening stage of the fruit and the extraction method. The addition of pectin to bakery products can change their texture, WHC, and consistency behavior. The addition of pectin can also extend the shelf life and be used to replace fat due to their high oil-holding capacity, thus reducing calories without losing taste [60].

\subsection{Gas Production and Dough Development Parameters during Fermentation}

Table 4 shows the effect of by-product addition on the fermentation characteristics of doughs. Gluten-free dough with DOP, DAP, DPP, DTP, DPP, and DPPSP was characterized by a higher maximum dough height $\left(\mathrm{H}_{\mathrm{m}}\right)$ compared to the gluten-free control dough, except for the dough with $2.5 \%$ DOP and $7.5 \%$ DPP, while this parameter was lower for the control wheat dough. Overall, the gluten-free dough with DAP, DTP, and DPPP had higher maximum dough heights $\left(\mathrm{H}_{\mathrm{m}}\right)$ than the other samples.

The maximum height of gas release $\left(\mathrm{H}_{\mathrm{m}}^{\prime}\right)$ of the gluten-free dough increased with the addition of selected dried peels at various levels, except for the $5 \%$ and $7.5 \%$ DOP addition. The time $\left(\mathrm{T}_{1}\right)$ to achieve the maximum dough development ranged from $25 \mathrm{~min}$ to $84 \mathrm{~min}$. Overall, all by-products at different levels reduced the time at maximum height $\left(\mathrm{T}_{1}\right)$ compared to the wheat dough (at $63 \mathrm{~min}$ ) and gluten-free dough (at $84 \mathrm{~min}$ ). The increase in the $\mathrm{H}_{\mathrm{m}}^{\prime}$ value and the decrease in the $\mathrm{T}_{1}$ value could be related to the accelerated kinetics of $\mathrm{CO}_{2}$ formation after adding the dried peels.

The time of maximum gas formation $\left(\mathrm{T}^{\prime}{ }_{1}\right)$ was influenced differently by each dried peel at different levels of addition. The same $\mathrm{T}^{\prime}{ }_{1}$ value $(45 \mathrm{~min})$ was demonstrated for the gluten-free control dough and the DOP dough with $2.5 \%$ and $5 \%$ addition. The time of porosity (Tx) of all samples with by-products appeared earlier than the Tx of the control wheat dough $(55.30 \mathrm{mn})$ and the gluten-free control dough $(31.30 \mathrm{mn})$. The maximum dough height $\left(\mathrm{H}_{\mathrm{m}}\right)$ of all samples was reached after the Tx. Verheyen, Jekle [61] indicated that the time when gas started to escape from the dough $\mathrm{Tx}$ and its retention capacity was related to the $\mathrm{CO}_{2}$ volume and the dough rheology. The addition of $7.5 \%$ DOP reduced the final dough height (h) to $0.9 \mathrm{~mm}$.

Loss of dough volume $\mathrm{W}$ (weakening coefficient) after $90 \mathrm{~min}$ was high for all samples compared to the gluten-free and wheat controls, except for the 2.5\% DPPSP addition for which the $\mathrm{T}_{1}$ increased $(61: 30 \mathrm{mn})$. The lower weakening coefficient $(3.4 \%)$ and the higher final height $(\mathrm{h})(5.6 \mathrm{~mm})$ indicated that gluten-free dough with 2.5\% DPPSP produced a dough with a stronger structure compared to all other samples. 
Table 4. Dough development and gas production parameters of wheat bread and gluten-free bread with and without added by-products.

\begin{tabular}{|c|c|c|c|c|c|c|c|c|c|c|c|c|c|}
\hline & $\begin{array}{c}\text { Addition } \\
\text { Level } \\
\%\end{array}$ & $\begin{array}{l}\mathrm{H}_{\mathrm{m}} \\
\mathrm{mm}\end{array}$ & $\begin{array}{l}\mathbf{H}_{\mathrm{m}}^{\prime} \\
\mathbf{m m}\end{array}$ & $\begin{array}{c}T_{1} \\
\min \end{array}$ & $\begin{array}{l}T_{1}^{\prime} \\
\min \end{array}$ & $\begin{array}{c}T_{x} \\
\min \end{array}$ & $\begin{array}{c}\mathrm{h} \\
\mathrm{mm}\end{array}$ & $\begin{array}{l}\mathrm{W} \\
\%\end{array}$ & $\begin{array}{c}\mathrm{V}_{\mathrm{tCO} 2} \\
\mathrm{~mL}\end{array}$ & $\begin{array}{l}\mathrm{V}_{1 \mathrm{CO} 2} \\
\mathrm{~mL}\end{array}$ & $\begin{array}{c}\mathrm{V}_{\mathrm{rCO} 2} \\
\mathrm{~mL}\end{array}$ & $\begin{array}{c}\mathrm{R}_{\mathrm{CO} 2} \\
\%\end{array}$ & $\begin{array}{c}\mathrm{H}_{\mathrm{adj}} \mathrm{m} \\
\mathrm{mm}\end{array}$ \\
\hline $\begin{array}{l}\text { Wheat } \\
\text { CTRL } 1\end{array}$ & 0 & 34.6 & 77.4 & $63: 0$ & $43: 30$ & $55: 30$ & 32.6 & 5.8 & 939 & 37 & 902 & 96.1 & 34.6 \\
\hline GF CTRL 2 & 0 & 4.1 & 96.3 & $84: 0$ & $45: 00$ & $31: 30$ & 3.9 & 4.9 & 874 & 259 & 615 & 70.4 & 4.10 \\
\hline \multirow{3}{*}{$\begin{array}{c}\text { CTRL } \\
2+\mathrm{DOP}\end{array}$} & 2.5 & 4.0 & 98.1 & $30: 0$ & $45: 00$ & $30: 00$ & 3.2 & 20.0 & 979 & 80 & 899 & 91.9 & 3.57 \\
\hline & 5 & 5.0 & 91.9 & $28: 3$ & $45: 00$ & $25: 30$ & 1.6 & 68.0 & 943 & 89 & 854 & 90.6 & 4.63 \\
\hline & 7.5 & 6.6 & 85.3 & $31: 3$ & $57: 00$ & $28: 30$ & 0.9 & 86.4 & 953 & 91 & 862 & 90.5 & 6.05 \\
\hline \multirow{3}{*}{$\begin{array}{l}\text { CTRL } 2 \\
+ \text { DAP }\end{array}$} & 2.5 & 6.5 & 104.7 & $39: 0$ & $49: 30$ & $27: 00$ & 2.4 & 63.1 & 1151 & 144 & 1006 & 87.5 & 4.94 \\
\hline & 5 & 7.8 & 105.0 & $43: 30$ & $55: 30$ & $31: 30$ & 2.4 & 69.2 & 1179 & 132 & 1047 & 88.8 & 5.78 \\
\hline & 7.5 & 7.5 & 103.9 & $30: 0$ & $54: 00$ & $28: 30$ & 3.3 & 56.0 & 1221 & 164 & 1058 & 86.6 & 5.37 \\
\hline \multirow{3}{*}{$\begin{array}{c}\text { CTRL } \\
2+\mathrm{DPP}\end{array}$} & 2.5 & 5.9 & 106.8 & $52: 30$ & $43: 30$ & 24:00 & 5.0 & 15.3 & 1083 & 107 & 975 & 90.1 & 4.76 \\
\hline & 5 & 6.4 & 103.0 & $36: 00$ & $36: 00$ & 24:00 & 4.0 & 37.5 & 1004 & 114 & 890 & 88.7 & 5.57 \\
\hline & 7.5 & 3.9 & 100.3 & $39: 00$ & $39: 00$ & $25: 30$ & 2.3 & 41.0 & 996 & 100 & 896 & 90.0 & 3.42 \\
\hline \multirow{3}{*}{$\begin{array}{c}\text { CTRL } \\
2+\mathrm{DTP}\end{array}$} & 2.5 & 8.2 & 98.8 & 39:00 & $40: 30$ & $27: 00$ & 1.0 & 87.8 & 1014 & 98 & 917 & 90.3 & 7.07 \\
\hline & 5 & 6.5 & 102.2 & $31: 30$ & $36: 00$ & $27: 00$ & 1.4 & 78.5 & 969 & 96 & 874 & 90.1 & 5.86 \\
\hline & 7.5 & 7.7 & 97.6 & $25: 30$ & $33: 00$ & $25: 30$ & 1.6 & 79.2 & 937 & 90 & 848 & 90.4 & 7.18 \\
\hline \multirow{3}{*}{$\begin{array}{c}\text { CTRL } \\
2+\mathrm{DPPP}\end{array}$} & 2.5 & 7.6 & 108.3 & 48:00 & $46: 30$ & $22: 30$ & 4.0 & 47.4 & 1118 & 103 & 1015 & 90.8 & 5.94 \\
\hline & 5 & 7.8 & 109.1 & $36: 00$ & $42: 00$ & $24: 00$ & 3.6 & 53.8 & 1136 & 148 & 988 & 87.0 & 6.00 \\
\hline & 7.5 & 5.8 & 105.7 & $58: 30$ & $46: 30$ & $24: 00$ & 4.8 & 17.2 & 1166 & 158 & 1008 & 86.4 & 4.35 \\
\hline \multirow{3}{*}{$\begin{array}{c}\text { CTRL } \\
2+\mathrm{DPPSP}\end{array}$} & 2.5 & 5.8 & 105.6 & $61: 30$ & $43: 30$ & $28: 30$ & 5.6 & 3.4 & 1070 & 100 & 970 & 90.6 & 4.74 \\
\hline & 5 & 4.7 & 102.8 & $43: 30$ & $37: 30$ & $24: 00$ & 3.3 & 29.8 & 993 & 105 & 887 & 89.4 & 4.14 \\
\hline & 7.5 & 5.7 & 106.3 & $31: 30$ & $33: 00$ & $27: 00$ & 4.6 & 19.3 & 969 & 97 & 872 & 90.0 & 5.14 \\
\hline
\end{tabular}

DOP: dried orange pomace; DAP: dried apple pomace; DTP: dried tomato peel; DPP: dried pepper peel; DPPP: dried prickly pear peel; DPPSP: dried prickly pear seed peel; CTRL: control; GF: gluten-free; $\mathrm{H}_{\mathrm{m}}$ : maximum height of dough; $\mathrm{T}_{1}$ : time at maximum height of dough; $\mathrm{H}^{\prime}{ }_{\mathrm{m}}$ : maximum height of gaseous release; $\mathrm{T}_{1}{ }_{1}$ : the time of maximum gas formation; $\mathrm{h}$ : height of dough at the end of the test; $\mathrm{W}$ : weakening coefficient $=\left(\mathrm{H}_{\mathrm{m}}-\mathrm{h}\right) / \mathrm{H}_{\mathrm{m}} ; \mathrm{V}_{\mathrm{t}}$ : total $\mathrm{CO}_{2}$ production volume; $\mathrm{V}_{\mathrm{l}}$ : volume of $\mathrm{CO}_{2}$ loss; $\mathrm{V}_{\mathrm{r}}$ : volume of $\mathrm{CO}_{2}$ retained; R: retention coefficient of $\mathrm{CO}_{2} ; \mathrm{H}_{\mathrm{m}}$ adj: adjusted maximum height.

The addition of selected dried peels at various levels to gluten-free doughs increased the total volume of $\mathrm{CO}_{2}$ production $\left(\mathrm{V}_{\mathrm{t}}\right)$, decreased the volume of $\mathrm{CO}_{2}$ loss $\left(\mathrm{V}_{1}\right)$, and increased the volume of $\mathrm{CO}_{2}$ retained $\left(\mathrm{V}_{\mathrm{r}}\right)$ as well as the $\mathrm{CO}_{2}$ retention coefficient $(\mathrm{R})$, which means that the addition of by-products improves the production and the retention capability of $\mathrm{CO}_{2}$ compared to the non-enriched gluten-free dough.

Significant gas production and retention have a positive effect on the final quality of the bread, as reported by Martínez and Díaz [34]. The $\mathrm{CO}_{2}$ retention capacity depends on the ingredients used and internal structure of the dough. The adjusted maximum height $\left(\mathrm{H}^{\text {adj }}{ }_{m}\right)$ of all samples was found to be lower than $\mathrm{H}_{m}$ after the yeast activity effect was isolated, which explains that the $\mathrm{Hm}$ was related to yeast activity and not only to dough rheology, where the selected by-products accelerated yeast activity.

The by-products used contained fermentable sugars such as glucose and fructose [20,62] and minerals such as $\mathrm{K}^{+}, \mathrm{Ca}^{2+}$, and $\mathrm{Zn}^{2+}[63,64]$. The yeast cells consume the fermenting sugars in the dough directly from the by-products or after pre-hydrolyzing the corn starch or chickpea flour, and produce carbon dioxide and ethanol, which are responsible for acidifying the dough during fermentation and the growth phase in the oven. On the other hand, the presence of the $\mathrm{Ca}^{2+}$ in fermentation media allows for maximum fermentation efficiency through increased alcohol production $[65,66]$.

\subsection{Rheological Properties of Dough}

The coefficient of consistency (K), flow behavior index (n), r-value (statistical correlation coefficient), and chi-square $(\chi 2)$ are presented in Table 5 . The power-law model showed low chi-square $(\chi 2)$ and high values of the correlation coefficient $(r)$ for all samples. The value of consistency coefficient ranged between 103 and 1049 Pa. $s^{\mathrm{n}}$. The highest values of the K consistency coefficient were observed for DPPP addition and then DPPSP. The lowest values were found in the samples of DPP dough. There was no statistically significant difference between the K consistency coefficient of the control bread and DOP, DAP, and DPP at the $2.5 \%$ and $5 \%$ additive levels and between the K of DTP at the $5 \%$ 
additive level and DPPSP at the $2.5 \%$ and $5 \%$ additive levels. As the amount of DOP, DAP, DPP, or DTP increased in the dough, the K consistency coefficient decreased. This could be related to the pre-hydration of the by-products before adding them to the dough, where the water absorption and the consistency of the dough are reduced. The flow behavior index ranged from -0.436 to 0.33 . In accordance with Ronda, Pérez-Quirce [35], the $n$ values of gluten-free dough ranged between 0.25 and 0.35 . Then, values of flow behavior index of whole dough were less than 1 , indicating pseudo-plasticity (shear thinning) of the samples. In the case of pseudoplastic substances, the viscosity decreases with the increase in the shear rate because the connections between the device components break down as a result of shearing, which, under the influence of shear, decomposes the interactions between the components of the system [67]. Increasing levels of DOP, DPP, and DPPP additive reduced the value of the flow behavior $n$ index of these samples.

Table 5. Rheological parameters of wheat bread and gluten-free bread with and without added by-products.

\begin{tabular}{|c|c|c|c|c|c|}
\hline & $\begin{array}{c}\text { Addition Level } \\
(\%)\end{array}$ & $\begin{array}{c}K \\
\left(\text { Pa.s }^{n}\right)\end{array}$ & $\mathbf{n}$ & $x^{2}$ & $\mathbf{r}$ \\
\hline WheatCTRL 1 & 0 & $141.90 \pm 25.74^{\mathrm{e}}$ & $0.33 \pm 0.04^{a}$ & $0.25 \pm 0.06$ & $0.97 \pm 0.007$ \\
\hline GF CTRL 2 & 0 & $173.30 \pm 20.08$ de & $0.29 \pm 0.02^{\mathrm{ab}}$ & $0.47 \pm 0.26$ & $0.97 \pm 0.007$ \\
\hline DOP & $\begin{array}{c}2.5 \\
5 \\
7.5 \\
\end{array}$ & $\begin{array}{c}216.60 \pm 134.49^{\mathrm{de}} \\
221.70 \pm 48.93^{\mathrm{de}} \\
134.55 \pm 9.83^{\mathrm{e}}\end{array}$ & $\begin{array}{c}0.08 \pm 0.01 \text { bcdefg } \\
-0.11 \pm 0.09 \text { abcde } \\
-0.25 \pm 0.04 \text { efg }\end{array}$ & $\begin{array}{l}1.77 \pm 0.40 \\
5.21 \pm 3.76 \\
0.94 \pm 0.14\end{array}$ & $\begin{array}{c}0.93 \pm 0.01 \\
0.88 \pm 0.04 \\
0.98 \pm 0.004\end{array}$ \\
\hline DAP & $\begin{array}{c}2.5 \\
5 \\
7.5\end{array}$ & $\begin{array}{c}337.30 \pm 95.74 \text { bcde } \\
291.40 \pm 22.84 \text { de } \\
159.60 \pm 21.64{ }^{\mathrm{e}}\end{array}$ & $\begin{array}{c}0.10 \pm 0.06^{\text {abcde }} \\
-0.12 \pm 0.02 \text { fg } \\
0.03 \pm 0.02^{\text {abcdef }}\end{array}$ & $\begin{array}{l}0.54 \pm 0.27 \\
4.88 \pm 2.67 \\
4.37 \pm 0.05\end{array}$ & $\begin{array}{l}0.98 \pm 0.01 \\
0.89 \pm 0.06 \\
0.87 \pm 0.01\end{array}$ \\
\hline DPP & $\begin{array}{c}2.5 \\
5 \\
7.5\end{array}$ & $\begin{array}{c}289.65 \pm 130.74^{\text {cde }} \\
182.76 \pm 67.76^{\mathrm{e}} \\
103.71 \pm 39.73^{\mathrm{e}}\end{array}$ & $\begin{array}{c}0.05 \pm 0.05^{\text {abcde }} \\
0.17 \pm 0.04^{\text {abcd }} \\
0.23 \pm 0.08^{a b c}\end{array}$ & $\begin{array}{l}0.86 \pm 0.62 \\
1.73 \pm 1.19 \\
0.28 \pm 0.17\end{array}$ & $\begin{array}{l}0.97 \pm 0.02 \\
0.87 \pm 0.05 \\
0.98 \pm 0.01\end{array}$ \\
\hline DTP & $\begin{array}{c}2.5 \\
5 \\
7.5\end{array}$ & $\begin{array}{c}955.40 \pm 323.29^{\mathrm{ab}} \\
229.05 \pm 80.40^{\mathrm{de}} \\
125.75 \pm 20.7^{\mathrm{e}}\end{array}$ & $\begin{array}{c}-0.20 \pm 0.00^{\text {defg }} \\
0.14 \pm 0.01^{\text {cdefg }} \\
0.162 \pm 0.08^{\text {abcde }}\end{array}$ & $\begin{array}{l}2.83 \pm 0.46 \\
1.15 \pm 1.43 \\
0.05 \pm 0.03\end{array}$ & $\begin{array}{l}0.94 \pm 0.01 \\
0.95 \pm 0.06 \\
0.99 \pm 0.00\end{array}$ \\
\hline DPPP & $\begin{array}{c}2.5 \\
5 \\
7.5\end{array}$ & $\begin{array}{l}822.70 \pm 37.62^{\mathrm{abcd}} \\
1049.00 \pm 548.71^{\mathrm{a}} \\
895.85 \pm 106.84^{\mathrm{abc}}\end{array}$ & $\begin{array}{c}-0.211 \pm 0.24 \text { defg } \\
-0.376 \pm 0.16^{\mathrm{fg}} \\
-0.436 \pm 0.06^{\mathrm{g}}\end{array}$ & $\begin{array}{l}4.93 \pm 5.68 \\
8.17 \pm 2.11 \\
4.92 \pm 1.84\end{array}$ & $\begin{array}{l}0.92 \pm 0.07 \\
0.92 \pm 0.01 \\
0.93 \pm 0.02\end{array}$ \\
\hline DPPSP & $\begin{array}{c}2.5 \\
5 \\
7.5\end{array}$ & $\begin{array}{l}399.0 \pm 285.81 \text { abcde } \\
434.35 \pm 63.00 \text { abcde } \\
480.05 \pm 24.54 \text { abcde }\end{array}$ & $\begin{array}{c}0.033 \pm 0.12 \text { abcdef } \\
-0.078 \pm 0.17^{\text {abcdefg }} \\
-0.03 \pm 0.18^{\text {abcdefg }}\end{array}$ & $\begin{array}{l}1.12 \pm 1.03 \\
4.53 \pm 3.01 \\
2.31 \pm 3.10\end{array}$ & $\begin{array}{l}0.96 \pm 0.02 \\
0.90 \pm 0.03 \\
0.95 \pm 0.06\end{array}$ \\
\hline$P$ & & $<0.0001$ & $<0.0001$ & & \\
\hline F & & 6.48 & 7.50 & & \\
\hline
\end{tabular}

DOP: dried orange pomace; DAP: dried apple pomace; DTP: dried tomato peel; DPP: dried pepper peel; DPPP: dried prickly pear peel; DPPSP: dried prickly pear seed peel; CTRL: control; GF: gluten-free; K: consistency coefficient; n: flow behavior index; r: statistical correlation coefficient; $\chi 2$ : chi-square; $P$ : $p$-value probability; F: F-value Fisher; a-g letters indicate a statistical different of means in the same column $(p<0.05)$.

According to Cheremisinoff [68] and Ronda, Pérez-Quirce [35], the coefficient of consistency $\mathrm{k}$ and the flow behavior index $\mathrm{n}$ depend on temperature, pressure, and formulation. While $\mathrm{k}$ is more temperature-sensitive than $\mathrm{n}$ on the non-Newtonian liquid food [69], the suspension becomes less viscous as temperature increases and more viscous when pressurized [70]. The flow behavior index varies depending on the formulation, in particular the hydration of the dough. Some samples showed a negative value of the flow behavior index $n$. There are very few studies that explain the negative values for the flow behavior index. These negative values can be attributed to the presence of slippage in the fluid, viscosity dispersion, or molecular degradation of the sample [71-73]. 


\subsection{Characteristics of the Quality of Bread}

The weight loss, specific volume, $\mathrm{pH}$-value, and moisture content of various breads are presented in Table 6 .

Table 6. Basic properties of wheat bread and gluten-free bread with and without added by-products.

\begin{tabular}{|c|c|c|c|c|c|}
\hline & $\begin{array}{c}\text { Level Addition } \\
\text { (\%) }\end{array}$ & $\begin{array}{l}\text { WL } \\
(\%)\end{array}$ & $\begin{array}{c}\mathrm{Vsp} \\
\left(\mathrm{cm}^{3} / \mathrm{g}\right)\end{array}$ & pH-Value & $\begin{array}{c}\text { Moisture Content } \\
(\%)\end{array}$ \\
\hline Wheat CTRL 1 & 0 & $25 \pm 0.015^{b c d}$ & $3.39 \pm 0.02^{a}$ & $5.65 \pm 0.02 \mathrm{gh}$ & $27.21 \pm 0.01^{\mathrm{k}}$ \\
\hline GF CTRL 2 & 0 & $18.09 \pm 0.22$ gh & $1.48 \pm 0.22^{\mathrm{i}}$ & $5.76 \pm 0.12^{c}$ & $29.60 \pm 0.23^{h}$ \\
\hline DOP & $\begin{array}{c}2.5 \\
5 \\
7.5 \\
\end{array}$ & $\begin{array}{c}18.33 \pm 2.35^{\mathrm{h}} \\
26.11 \pm 0.78^{\mathrm{ab}} \\
27.77 \pm 1.57^{\mathrm{a}}\end{array}$ & $\begin{array}{l}2.00 \pm 0.03^{\mathrm{f}} \\
2.25 \pm 0.02^{\mathrm{c}} \\
2.46 \pm 0.05^{\mathrm{b}}\end{array}$ & $\begin{array}{l}5.59 \pm 0.06^{\mathrm{k}} \\
5.26 \pm 0.23^{\mathrm{n}} \\
5.21 \pm 0.50^{\mathrm{o}}\end{array}$ & $\begin{array}{l}31.13 \pm 0.06^{\mathrm{a}} \\
30.19 \pm 0.42^{\mathrm{d}} \\
30.02 \pm 0.50^{\mathrm{f}}\end{array}$ \\
\hline DAP & $\begin{array}{c}2.5 \\
5 \\
7.5\end{array}$ & $\begin{array}{l}23.88 \pm 0.78^{\text {cde }} \\
26.66 \pm 3.14^{\mathrm{ab}} \\
25.55 \pm 0.00^{\mathrm{bc}}\end{array}$ & $\begin{array}{l}2.02 \pm 0.08^{\mathrm{f}} \\
2.04 \pm 0.01^{\mathrm{f}} \\
2.16 \pm 0.10^{\text {ef }}\end{array}$ & $\begin{array}{c}5.68 \pm 0.16^{\text {ef }} \\
5.58 \pm 0.03^{1} \\
5.51 \pm 0.01^{\mathrm{m}}\end{array}$ & $\begin{array}{l}30.24 \pm 0.04^{\mathrm{d}} \\
30.20 \pm 0.16^{\mathrm{d}} \\
30.42 \pm 0.01^{\mathrm{c}}\end{array}$ \\
\hline DPP & $\begin{array}{c}2.5 \\
5 \\
7.5\end{array}$ & $\begin{array}{l}20.45 \pm 0.37^{f} \\
20.45 \pm 0.29^{f} \\
20.51 \pm 0.33^{f}\end{array}$ & $\begin{array}{c}1.69 \pm 0.01^{\mathrm{h}} \\
2.04 \pm 0.06^{\mathrm{f}} \\
2.10 \pm 0.10^{\mathrm{de}}\end{array}$ & $\begin{array}{c}5.68 \pm 0.36^{\mathrm{fg}} \\
5.57 \pm 0.20^{1} \\
5.63 \pm 0.40^{\mathrm{i}}\end{array}$ & $\begin{array}{l}29.57 \pm 0.36^{h} \\
29.63 \pm 0.29^{h} \\
30.72 \pm 0.12^{b}\end{array}$ \\
\hline DTP & $\begin{array}{c}2.5 \\
5\end{array}$ & $\begin{array}{c}23.88 \pm 0.78^{\text {cde }} \\
23.33 \pm 0.00^{\text {de }}\end{array}$ & $\begin{array}{l}2.21 \pm 0.02^{\mathrm{cd}} \\
2.10 \pm 0.10^{\mathrm{ef}}\end{array}$ & $\begin{array}{l}5.57 \pm 0.08^{1} \\
5.66 \pm 0.10^{h}\end{array}$ & $\begin{array}{l}29.01 \pm 0.20^{\mathrm{i}} \\
29.57 \pm 0.08^{\mathrm{h}}\end{array}$ \\
\hline & 7.5 & $19.42 \pm 0.007^{\mathrm{fg}}$ & $2.20 \pm 0.00^{\mathrm{cd}}$ & $5.70 \pm 0.01^{\mathrm{e}}$ & $29.57 \pm 0.40^{h}$ \\
\hline DPPP & $\begin{array}{c}2.5 \\
5 \\
7.5 \\
\end{array}$ & $\begin{array}{l}19.05 \pm 0.01^{\mathrm{fg}} \\
19.28 \pm 0.08^{\mathrm{fg}} \\
22.76 \pm 0.16^{\mathrm{e}}\end{array}$ & $\begin{array}{c}1.83 \pm 0.00 \mathrm{~g} \\
2.50 \pm 0.04^{\mathrm{b}} \\
2.15 \pm 0.004^{\mathrm{de}} \\
\end{array}$ & $\begin{array}{l}5.73 \pm 0.40^{\mathrm{d}} \\
5.80 \pm 0.14^{\mathrm{b}} \\
5.68 \pm 0.03^{\mathrm{fg}}\end{array}$ & $\begin{array}{l}30.00 \pm 0.03^{\mathrm{e}} \\
30.35 \pm 0.09^{\mathrm{c}} \\
29.70 \pm 0.21^{\mathrm{g}}\end{array}$ \\
\hline DPPSP & $\begin{array}{c}2.5 \\
5 \\
7.5 \\
\end{array}$ & $\begin{array}{c}20.32 \pm 0.10^{\mathrm{f}} \\
20.84 \pm 0.48^{\mathrm{f}} \\
20.9 \pm 0.26^{\mathrm{f}}\end{array}$ & $\begin{array}{l}1.72 \pm 0.08^{\mathrm{h}} \\
1.72 \pm 0.04^{\mathrm{h}} \\
2.02 \pm 0.20^{\mathrm{f}}\end{array}$ & $\begin{array}{l}5.61 \pm 0.08^{\mathrm{i}} \\
5.61 \pm 0.04^{\mathrm{i}} \\
5.87 \pm 0.06^{\mathrm{a}}\end{array}$ & $\begin{array}{l}28.71 \pm 0.12^{\mathrm{j}} \\
30.20 \pm 0.05^{\mathrm{d}} \\
30.22 \pm 0.03^{\mathrm{d}}\end{array}$ \\
\hline $\mathbf{P}$ & & $<0.0001$ & $<0.0001$ & $<0.0001$ & $<0.0001$ \\
\hline$F$ & & 22.34 & 181.02 & 1056.020 & 10211.024 \\
\hline
\end{tabular}

DOP: dried orange pomace; DAP: dried apple pomace; DTP: dried tomato peel; DPP: dried pepper peel; DPPP: dried prickly pear peel; DPPSP: dried prickly pear seed peel; CTRL: control; GF: gluten-free; WL: weight loss; Vsp: specific volume; P: $p$-value probability; F: F-value Fishera-o letters indicate a statistical different of means in the same column $(p<0.05)$.

\subsubsection{Weight Loss}

Table 6 shows that the weight loss was greater for all formulas compared to the glutenfree control bread $(p<0.05)$. There was no significant difference in the weight loss values of bread containing different amounts of DPP and DPPSP by-products. The weight loss of gluten-free bread increased with increasing levels of DOP, DAP, and DPPP, but decreased with increasing levels of DTP. At high DOP, DAP, or DPPP values, the water cannot be retained in the bread. This may be due to the water-holding capacity of the by-products. Weight loss before and after baking of bread is generally specifically associated with water loss. The addition of pre-hydration by-products increased the water loss during baking, which increased the weight loss of the bread [52]. Compared to the gluten-free control bread, the percent weight loss was greater for the wheat control bread, the DOP bread, and the DAP bread at $5 \%$ and $7.5 \%$ additions. Furthermore, DOP bread with $2.5 \%$ addition resulted in little weight loss (18.33\%). Regarding the WL results, the samples with DPPP proved to be more effective in reducing weight loss (19.05-22.76\%). In the study of Milde, Ramallo [74], low weight loss was sought to ensure a moisture content that impeded the dehydration of bread and to reduce the hardness. 


\subsubsection{Specific Volume of Bread}

The specific volume of gluten-free bread varies depending on the ingredients and the preparation process [75]. The addition of by-products influences the specific volume of bread to a different extent $(p<0.0001)$. The specific volume of gluten-free bread ranged from 1.48 to $2.50 \mathrm{~cm}^{3} / \mathrm{g}$. All formulas had a much higher specific volume compared to the gluten-free control bread $\left(1.48 \mathrm{~cm}^{3} / \mathrm{g}\right)$, but a lower specific volume compared to the wheat control bread $\left(3.39 \mathrm{~cm}^{3} / \mathrm{g}\right)$

The specific volume was the highest for DPPP bread at $5 \%\left(2.50 \mathrm{~cm}^{3} / \mathrm{g}\right)$, followed by DOP $\left(2.46 \mathrm{~cm}^{3} / \mathrm{g}\right)$ at $7.5 \%$, and the lowest specific volume was recorded for DPP bread $\left(1.69 \mathrm{~cm}^{3} / \mathrm{g}\right)$ with an addition of $2.5 \%$. These results are supported by $\mathrm{O}^{\prime}$ shea et al. [76] with $4 \%$ addition of orange pomace. There were no significant differences between the specific volume of DOP bread at $2.5 \%$, DAP bread at $2.5 \%$, and DPP bread at $5 \%$ addition.

Overall, the specific volume increased with increasing levels of by-products, with a maximum found at $7.5 \%(w / w)$. These results are supported by Arslan et al. [77], who studied the effect of powdered guava pulp on gluten-free bread, Singh et al. [78], who assessed the effect of dietary fiber from black carrot pomace on gluten-free rice muffins, and TÜrKEr et al. [79], who investigated the effects of the green banana peel on gluten-free cakes. According to these authors, adding more than $7.5 \%$ by-products reduced the specific volume of gluten-free products. Parra et al. [75] reported that the right balance between the amount of apple pomace and water allowed for a gluten-free bread with an acceptable specific volume to be obtained.

\subsection{3. $\mathrm{pH}$ Value of Bread}

The $\mathrm{pH}$ value of bread ranged from 5.21 to 5.87. Except for 5\% DPPP bread and 7.5\% DPPSP bread, all formulas had a significantly lower $\mathrm{pH}$ value than gluten-free control bread $(p<0.05)$. The $\mathrm{pH}$ values were similar for DPP bread at $7.5 \%$ and DPPSP bread at $2.5 \%$ and $5 \%$ additive levels. DTP and DPPSP increased the $\mathrm{pH}$ value of bread.

The $\mathrm{pH}$ of the gluten-free bread was reduced with the addition of DOP and DAP. Similar results were obtained by Majzoobi et al. [47] for carrot pomace powder, where the $\mathrm{pH}$ value of gluten-free cakes was reduced due to the presence of organic acid [80], amino acids $[81,82]$, and other acidic components.

\subsubsection{Moisture Content of Bread}

As shown in Table 6, the bread moisture content ranged from $27.21 \%$ to $31.13 \%$. The control wheat bread had the lowest value of moisture. The addition of DOP, DAP, DPPP, and DPPSP increased the moisture content of gluten-free bread. A lower value (28.71\%) was noted for DPPSP with $2.5 \%$ addition. The moisture content of the gluten-free bread was gradually increased with the gradual addition of DPP and DPPSP and decreased by the addition of DOP. The moisture content measurements showed no significant differences between gluten-free control bread, DPP bread with $2.5 \%$ and $5 \%$ addition, and DTP bread with $5 \%$ and $7.5 \%$ addition. Increased bread moisture contributes to an increase in the bread weight.

\subsubsection{Crust and Crumb Color of Bread}

The results concerning the color of the crust and crumbs are presented in Table 7. A golden brown crust and creamy white bread crumbs are the most important factors indicating the quality of a bakery product to consumers [5]. The addition of by-products had a significant $(p<0.05)$ effect on the color characteristics of crust and crumbs.

The lightness component ( $L^{*}$ for crumb and crust) decreased with the addition of by-products compared to the control wheat and gluten-free bread. For each by-product, the lightness of the crust and crumb color deceased as the level of the additive increased. 
Table 7. Crust and crumb colors of wheat bread and gluten-free bread with and without added by-products.

\begin{tabular}{|c|c|c|c|c|c|c|c|}
\hline & \multirow{2}{*}{$\begin{array}{l}\text { Addition } \\
\text { Level (\%) }\end{array}$} & \multicolumn{3}{|c|}{ Crust Color } & \multicolumn{3}{|c|}{ Crumb Color } \\
\hline & & $L^{*}$ & $a^{*}$ & $b^{*}$ & $L^{*}$ & $a^{*}$ & $b^{*}$ \\
\hline $\begin{array}{l}\text { Wheat } \\
\text { CTRL1 }\end{array}$ & 0 & $81.06 \pm 2.23^{a}$ & $4.78 \pm 1.69^{\text {cdef }}$ & $45.58 \pm 1.11^{\mathrm{k}}$ & $91.62 \pm 2.09^{a}$ & $-2.8 \pm 0.51 \mathrm{hi}$ & $24.18 \pm 3.54^{n}$ \\
\hline $\begin{array}{c}\text { GF } \\
\text { CTRL } 2\end{array}$ & 0 & $74.6 \pm 3.95 \mathrm{bc}$ & $4.4 \pm 1.54 \mathrm{def}$ & $53.96 \pm 2.06^{\text {bcdef }}$ & $80.42 \pm 2.62 \mathrm{bc}$ & $-1.64 \pm 0.70 \mathrm{gh}$ & $45.36 \pm 1.30$ de \\
\hline DOP & $\begin{array}{c}2.5 \\
5 \\
7.5 \\
\end{array}$ & $\begin{array}{l}69.46 \pm 9.63^{\mathrm{cd}} \\
58.82 \pm 3.02^{\mathrm{fgh}} \\
62.68 \pm 2.42^{\mathrm{efg}}\end{array}$ & $\begin{array}{c}2.075 \pm 1.69^{\mathrm{f}} \\
14.52 \pm 1.89^{\mathrm{bc}} \\
10.48 \pm 2.32^{\mathrm{bcdef}}\end{array}$ & $\begin{array}{c}47.84 \pm 1.96^{\mathrm{ijk}} \\
52.68 \pm 3.91^{\mathrm{defg}} \\
51.88 \pm 2.30^{\text {defgh }}\end{array}$ & $\begin{array}{c}66.86 \pm 0.96 \mathrm{gh} \\
68.4 \pm 2.27 \mathrm{fg} \\
65.84 \pm 1.32 \mathrm{gh}\end{array}$ & $\begin{array}{c}-0.64 \pm 0.42^{\mathrm{fg}} \\
-0.12 \pm 0.94^{\mathrm{ef}} \\
1.76 \pm 1.46^{\mathrm{cd}}\end{array}$ & $\begin{array}{c}34.42 \pm 1.49^{\mathrm{kl}} \\
35.24 \pm 2.05^{\mathrm{jk}} \\
40.36 \pm 1.28^{\mathrm{fgh}}\end{array}$ \\
\hline DAP & $\begin{array}{c}2.5 \\
5 \\
7.5\end{array}$ & $\begin{array}{c}66.58 \pm 6.88^{\mathrm{de}} \\
62.12 \pm 2.05^{\mathrm{efgh}} \\
63.56 \pm 3.72^{\text {ef }}\end{array}$ & $\begin{array}{l}9.58 \pm 2.93 \text { bcdef } \\
8.54 \pm 3.06^{\text {bcdef }} \\
5.82 \pm 1.89 \text { bcdef }\end{array}$ & $\begin{array}{c}54.25 \pm 3.32^{\text {bcde }} \\
50.88 \pm 3.35^{\text {fghi }} \\
46.36 \pm 2.60^{\mathrm{jk}}\end{array}$ & $\begin{array}{c}64.12 \pm 1.55^{\mathrm{hi}} \\
61.2 \pm 2.1^{\mathrm{ijk}} \\
60.74 \pm 1.95^{\mathrm{k}}\end{array}$ & $\begin{array}{c}0.00 \pm 1.33^{\text {ef }} \\
0.49 \pm 1.08^{\text {def }} \\
1.08 \pm 0.81^{\text {de }}\end{array}$ & $\begin{array}{l}33.2 \pm 1.47^{\mathrm{klm}} \\
31.66 \pm 1.06^{\mathrm{lm}} \\
31.66 \pm 1.06^{\mathrm{m}}\end{array}$ \\
\hline DPP & $\begin{array}{c}2.5 \\
5\end{array}$ & $\begin{array}{l}70.88 \pm 4.12^{\mathrm{cd}} \\
71.08 \pm 3.32^{\mathrm{cd}}\end{array}$ & $\begin{array}{l}10.32 \pm 2.48^{\text {bcdef }} \\
12.88 \pm 2.29 \text { bcde }\end{array}$ & $\begin{array}{c}56.1 \pm 1.04^{\mathrm{abc}} \\
54.64 \pm 1.38^{\mathrm{abcd}}\end{array}$ & $\begin{array}{c}72.56 \pm 6.52^{\text {de }} \\
78.94 \pm 1.47^{c}\end{array}$ & $\begin{array}{l}3.48 \pm 1.49^{b} \\
3.32 \pm 1.02^{b}\end{array}$ & $\begin{array}{l}44.14 \pm 2.17^{\mathrm{e}} \\
47.48 \pm 1.22^{\mathrm{bc}}\end{array}$ \\
\hline & 7.5 & $66.84 \pm 5.78^{\mathrm{de}}$ & $15.48 \pm 2.64^{b}$ & $53.2 \pm 1.97^{\text {cdefg }}$ & $70.5 \pm 1.54^{\mathrm{ef}}$ & $9.00 \pm 0.44^{\mathrm{a}}$ & $48.58 \pm 1.04^{b}$ \\
\hline DTP & $\begin{array}{c}2.5 \\
5 \\
7.5\end{array}$ & $\begin{array}{l}57.52 \pm 1.29^{\mathrm{h}} \\
56.7 \pm 2.28^{\mathrm{gh}} \\
62.68 \pm 2.7^{\mathrm{efg}}\end{array}$ & $\begin{array}{c}13.36 \pm 0.89 \text { bcde } \\
14.04 \pm 1.57 \text { bcd } \\
6.9 \pm 0.81^{\text {bcdef }}\end{array}$ & $\begin{array}{c}52.14 \pm 1.68^{\text {defgh }} \\
54.5 \pm 2.17^{\mathrm{bcd}} \\
54.66 \pm 0.86^{\text {abcd }}\end{array}$ & $\begin{array}{l}63.88 \pm 1.71^{\text {hij }} \\
60.86 \pm 1.21^{\mathrm{jk}} \\
74.06 \pm 1.52^{\mathrm{d}}\end{array}$ & $\begin{array}{l}1.82 \pm 1.25^{\mathrm{cd}} \\
3.98 \pm 0.89^{\mathrm{b}} \\
3.06 \pm 0.97^{\mathrm{bc}}\end{array}$ & $\begin{array}{c}38.92 \pm 2.03^{\mathrm{hi}} \\
42.04 \pm 2.12^{\mathrm{f}} \\
51.18 \pm 1.58^{\mathrm{a}}\end{array}$ \\
\hline DPPP & $\begin{array}{c}2.5 \\
5 \\
7.5 \\
\end{array}$ & $\begin{array}{l}70.56 \pm 3.13^{\mathrm{cd}} \\
69.66 \pm 3.59^{\mathrm{cd}} \\
56.86 \pm 9.17^{\mathrm{gh}}\end{array}$ & $\begin{array}{c}12.7 \pm 2.07^{\mathrm{a}} \\
7.46 \pm 1.42^{\mathrm{bcdef}} \\
14.58 \pm 1.74^{\mathrm{bc}}\end{array}$ & $\begin{array}{c}57.66 \pm 1.75^{\mathrm{a}} \\
56.64 \pm 2.46^{\mathrm{ab}} \\
51.22 \pm 3.91^{\text {efghi }}\end{array}$ & $\begin{array}{c}80.66 \pm 1.97^{b c} \\
80.48 \pm 2.99 b c \\
60.72 \pm 2.15^{k}\end{array}$ & $\begin{array}{c}-1.88 \pm 0.600^{\mathrm{gh}} \\
3.56 \pm 1.22^{\mathrm{i}} \\
3.70 \pm 1.81^{\mathrm{b}}\end{array}$ & $\begin{array}{l}46.06 \pm 1.24^{\mathrm{cde}} \\
46.24 \pm 1.79 \mathrm{~cd} \\
47.02 \pm 1.13^{\mathrm{bcd}}\end{array}$ \\
\hline DPPSP & $\begin{array}{c}2.5 \\
5 \\
7.5\end{array}$ & $\begin{array}{c}80.34 \pm 2.73^{\mathrm{ab}} \\
62.18 \pm 6.19^{\mathrm{efgh}} \\
73.28 \pm 4.81^{\mathrm{c}}\end{array}$ & $\begin{array}{c}3.36 \pm 1.18^{\text {ef }} \\
12.84 \pm 1.5^{\text {bcde }} \\
6.28 \pm 3.00^{\text {bcdef }}\end{array}$ & $\begin{array}{c}50.82 \pm 4.77 \mathrm{fghi} \\
50.68 \pm 1.40 \mathrm{ghi} \\
49.32 \pm 0.75 \mathrm{hij}\end{array}$ & $\begin{array}{c}82.2 \pm 2.05^{b} \\
74.46 \pm 3.28^{d} \\
77.74 \pm 2.39^{c}\end{array}$ & $\begin{array}{l}-1.86 \pm 0.82^{\mathrm{gh}} \\
0.25 \pm 0.36^{\mathrm{def}} \\
-0.24 \pm 0.87^{\mathrm{f}}\end{array}$ & $\begin{array}{c}41.04 \pm 0.79 \mathrm{fg} \\
39.62 \pm 0.71 \mathrm{gh} \\
37.06 \pm 1.35^{\mathrm{ij}}\end{array}$ \\
\hline $\mathbf{P}$ & & 0.0000 & 0.0000 & 0.0000 & 0.0000 & 0.0000 & 0.0000 \\
\hline F & & 11.81 & 2.72 & 8.26 & 63.74 & 39.66 & 86.24 \\
\hline
\end{tabular}

DOP: dried orange pomace; DAP: dried apple pomace; DTP: dried tomato peel; DPP: dried pepper peel; DPPP: dried prickly pear peel; DPPSP: dried prickly pear seed peel; CTRL: control; GF: gluten-free. P: $p$-value probability. F: F-value Fisher. a-n letters indicate a statistical different of means in the same column $(p<0.05)$.

Increased levels of DOP, DPP, DTP, and DPPP allowed increasing yellowness $\left(b^{*}\right)$ and redness $\left(a^{*}\right)$ of the gluten-free bread crumb. The gluten-free color of the bread crumb supplemented with by-products was directly correlated with the ingredients used in the production of the dough.

The color of bread depends on the formulation or baking condition. Maillard reactions and caramelization of the crust are responsible for the changes in the color parameters between the crust and the crumb and the development of brown color on the surface at high temperature, but the color given to the ingredients used in bread formulation may mask this color $[5,55,83,84]$.

\subsubsection{Crumb Structure of Bread}

The number of cells $/ \mathrm{mm}^{2}$, average size, pore area fraction, perimeter, circularity, and solidity of crumb cellular structure obtained from image analysis are shown in Table 8.

The number of cells $/ \mathrm{mm}^{2}$ ranged from 78 to 308 cells $/ \mathrm{mm}^{2}$. A higher number of cells $/ \mathrm{mm}^{2}$ is demonstrated for DPPP and DPP at $2.5 \%$ followed by DPPSP at $7.5 \%$, and a lower number was demonstrated for DOP at $5 \%$ and DAP at $2.5 \%$. A higher average size was obtained for the wheat control bread $(1.672 \mathrm{~mm})$. The average crumb size increased significantly with the addition of DAP, DPP, and DTP and decreased with the addition of DPPSP. Crumbs of the wheat control bread and DOP and DPPP at 5\% were characterized by a large perimeter.

Gluten-free bread with a large number of cells is characterized by an aerated structure against the crumbs with a small number of cells. According to Jafari et al. [85] the lower number of cells and the higher average size reflected the aerated structure. Solidity is a measure of the shape of disorder gas cells. The solidity value is lower for irregular 
shape of gas cells and higher for regular shape $[86,87]$. The solidity of samples ranged from 0.85 to 0.92 . The shape of the gas cells DPP at $5 \%$ and DPPSP at $2.5 \%$ had a regular structure and uniform shape (solidity $=0.91$ and 0.92 , respectively) and greater roundness (circularity $=0.91$ and 0.93 , respectively) compared to control gluten-free bread. The crumb appearance of control and enriched bread is shown in Figure 3.

Table 8. Crumb structure of wheat bread and gluten-free bread with and without added by-products.

\begin{tabular}{|c|c|c|c|c|c|c|c|}
\hline & & $\begin{array}{l}\text { Number of } \\
\text { Cells } / \mathrm{mm}^{2}\end{array}$ & $\begin{array}{l}\text { Average Cell } \\
\text { Size }\left(\mathrm{mm}^{2}\right)\end{array}$ & $\begin{array}{c}\text { Area Fraction } \\
(\%)\end{array}$ & Perimeter & Circularity & Solidity \\
\hline WheatCTRL1 & 0 & $203 \pm 8^{\text {bcd }}$ & $1.672 \pm 0.26^{\mathrm{a}}$ & $18.25 \pm 1.34^{\mathrm{a}}$ & $4.32 \pm 0.27^{\mathrm{a}}$ & $0.81 \pm 0.007^{\mathrm{i}}$ & $0.85 \pm 0.006^{f}$ \\
\hline GFCTRL 2 & 0 & $239 \pm 13^{a b c}$ & $0.46 \pm 0.12^{\text {cde }}$ & $12.85 \pm 3.18^{b c}$ & $2.28 \pm 0.29$ defgh & $0.87 \pm 0.01^{\text {cdefg }}$ & $0.87 \pm 0.00^{\text {cdef }}$ \\
\hline DOP & $\begin{array}{c}2.5 \\
5 \\
7.5 \\
\end{array}$ & $\begin{array}{c}122 \pm 23^{\text {ef }} \\
78 \pm 6^{\mathrm{f}} \\
100 \pm 0^{\mathrm{f}}\end{array}$ & $\begin{array}{c}0.55 \pm 0.19^{\text {cde }} \\
0.91 \pm 0.14^{b} \\
0.67 \pm 0.04^{b c}\end{array}$ & $\begin{array}{c}5.85 \pm 2.33 \mathrm{hi} \\
7.25 \pm 0.49 \mathrm{efgh} \\
5.9 \pm 0.57 \mathrm{ghi}\end{array}$ & $\begin{array}{c}2.64 \pm 0.50^{\mathrm{cdef}} \\
3.08 \pm 0.06^{\mathrm{bc}} \\
2.80 \pm 0.15^{\mathrm{bcd}}\end{array}$ & $\begin{array}{c}0.85 \pm 0.02^{\mathrm{gh}} \\
0.86 \pm 0.01^{\mathrm{cdefg}} \\
0.86 \pm 0.01^{\mathrm{hi}}\end{array}$ & $\begin{array}{l}0.86 \pm 0.00^{\text {def }} \\
0.881 \pm 0.01^{\mathrm{cd}} \\
0.85 \pm 0.01^{\text {def }}\end{array}$ \\
\hline DAP & $\begin{array}{c}2.5 \\
5 \\
7.5\end{array}$ & $\begin{array}{c}86 \pm 6^{\mathrm{f}} \\
116 \pm 20^{\mathrm{f}} \\
125 \pm 21^{\text {ef }}\end{array}$ & $\begin{array}{l}0.49 \pm 0.16^{\text {cde }} \\
0.61 \pm 0.09^{c d} \\
0.65 \pm 0.17^{b c}\end{array}$ & $\begin{array}{c}3.65 \pm 0.92^{\mathrm{i}} \\
6.57 \pm 2.21^{\mathrm{fghi}} \\
7.97 \pm 0.61^{\mathrm{efgh}}\end{array}$ & $\begin{array}{c}2.15 \pm 0.15^{\text {efgh }} \\
2.67 \pm 0.25^{\text {cde }} \\
2.80 \pm 0.32^{c d}\end{array}$ & $\begin{array}{c}0.89 \pm 0.03^{\text {bcde }} \\
0.86 \pm 0.02 \text { efgh } \\
0.85 \pm 0.02 \text { gh }\end{array}$ & $\begin{array}{c}0.89 \pm 0.03^{\mathrm{bc}} \\
0.87 \pm 0.01^{\mathrm{def}} \\
0.86 \pm 0.01^{\mathrm{ef}}\end{array}$ \\
\hline DPP & $\begin{array}{c}2.5 \\
5 \\
7.5 \\
\end{array}$ & $\begin{array}{c}308 \pm 25^{\mathrm{a}} \\
200 \pm 2^{\mathrm{cde}} \\
239 \pm 35^{\mathrm{abc}}\end{array}$ & $\begin{array}{c}0.34 \pm 0.05^{\mathrm{e}} \\
0.36 \pm 0.02^{\mathrm{de}} \\
0.37 \pm 0.02^{\mathrm{de}}\end{array}$ & $\begin{array}{l}11.65 \pm 1.91^{\mathrm{bcd}} \\
6.90 \pm 0.99 \mathrm{fghi} \\
9.25 \pm 0.78^{\mathrm{defg}}\end{array}$ & $\begin{array}{c}2.02 \pm 0.20^{\mathrm{gh}} \\
1.87 \pm 0.17^{\mathrm{h}} \\
2.08 \pm 0.07^{\mathrm{fgh}}\end{array}$ & $\begin{array}{c}0.88 \pm 0.02^{\text {cdef }} \\
0.91 \pm 0.00^{\mathrm{ab}} \\
0.89 \pm 0.01^{\mathrm{bc}}\end{array}$ & $\begin{array}{l}0.88 \pm 0.01^{\mathrm{cd}} \\
0.91 \pm 0.00^{\mathrm{ab}} \\
0.89 \pm 0.00^{\mathrm{bc}}\end{array}$ \\
\hline DTP & $\begin{array}{c}2.5 \\
5 \\
7.5 \\
\end{array}$ & $\begin{array}{l}210 \pm 9^{b c d} \\
262 \pm 37^{a b} \\
242 \pm 58^{a b c}\end{array}$ & $\begin{array}{l}0.46 \pm 0.12 \text { cde } \\
0.48 \pm 0.08^{\text {cde }} \\
0.50 \pm 0.03^{\text {cde }}\end{array}$ & $\begin{array}{c}9.30 \pm 1.25^{\mathrm{def}} \\
11.95 \pm 0.59^{\mathrm{bcd}} \\
10.30 \pm 3.11^{\mathrm{cde}}\end{array}$ & $\begin{array}{c}2.35 \pm 0.25^{\text {defgh }} \\
2.50 \pm 0.06^{\text {defg }} \\
2.35 \pm 0.01^{\text {defgh }}\end{array}$ & $\begin{array}{c}0.87 \pm 0.02^{\text {cdef }} \\
0.85 \pm 0.02 \mathrm{gh} \\
0.90 \pm 0.00^{\mathrm{bc}}\end{array}$ & $\begin{array}{c}0.88 \pm 0.00^{\text {cde }} \\
0.86 \pm 0.01^{\mathrm{f}} \\
0.89 \pm 0.00^{\mathrm{bc}}\end{array}$ \\
\hline DPPP & $\begin{array}{c}2.5 \\
5 \\
7.5 \\
\end{array}$ & $\begin{array}{l}308 \pm 8^{\mathrm{a}} \\
175 \pm 7^{\text {de }} \\
190 \pm 8^{\mathrm{cd}}\end{array}$ & $\begin{array}{c}0.52 \pm 0.05^{\text {cde }} \\
0.89 \pm 0.11^{\mathrm{b}} \\
0.49 \pm 0.19^{\text {cde }}\end{array}$ & $\begin{array}{c}14.10 \pm 0.42^{b c} \\
14.55 \pm 1.20^{b} \\
11.05 \pm 2.33^{c d}\end{array}$ & $\begin{array}{c}2.46 \pm 0.15^{\text {defgh }} \\
3.37 \pm 0.22^{\mathrm{b}} \\
2.39 \pm 0.52^{\text {defgh }}\end{array}$ & $\begin{array}{c}0.88 \pm 0.01^{\text {bcdef }} \\
0.86 \pm 0.01^{\text {defgh }} \\
0.85 \pm 0.01^{\text {fgh }}\end{array}$ & $\begin{array}{l}0.88 \pm 0.00^{\text {bcd }} \\
0.87 \pm 0.01^{\text {def }} \\
0.87 \pm 0.01^{\text {def }}\end{array}$ \\
\hline DPPSP & $\begin{array}{c}2.5 \\
5\end{array}$ & $\begin{array}{c}115 \pm 76^{\mathrm{f}} \\
223 \pm 56^{\mathrm{bcd}}\end{array}$ & $\begin{array}{l}0.59 \pm 0.31^{\text {cde }} \\
0.44 \pm 0.04^{\text {cde }}\end{array}$ & $\begin{array}{c}5.20 \pm 0.85^{\mathrm{hi}} \\
10.45 \pm 1.06^{\mathrm{cde}}\end{array}$ & $\begin{array}{c}2.37 \pm 0.63^{\text {defgh }} \\
2.20 \pm 0.01^{\text {efgh }}\end{array}$ & $\begin{array}{c}0.93 \pm 0.02^{\mathrm{a}} \\
0.90 \pm 0.03^{\mathrm{bcd}}\end{array}$ & $\begin{array}{l}0.92 \pm 0.00^{\mathrm{a}} \\
0.89 \pm 0.02^{\mathrm{bc}}\end{array}$ \\
\hline & 7.5 & $302 \pm 29^{a}$ & $0.43 \pm 0.09$ cde & $13.05 \pm 1.20^{b c}$ & $2.11 \pm 0.24 \mathrm{fgh}$ & $0.87 \pm 0.01^{\text {cdefg }}$ & $0.88 \pm 0.00^{\mathrm{cd}}$ \\
\hline $\mathbf{P}$ & & $<0.0001$ & 0.001 & $<0.0001$ & 0.004 & 0.000 & 0.001 \\
\hline $\mathbf{F}$ & & 12.15 & 9.16 & 10.34 & 8.00 & 7.414 & 6.653 \\
\hline
\end{tabular}

DOP: dried orange pomace; DAP: dried apple pomace; DTP: dried tomato peel; DPP: dried pepper peel; DPPP: dried prickly pear peel; DPPSP: dried prickly pear seed peel; CTRL: control; GF: gluten-free. P: $p$-value probability. F: F-value Fisher. a-i letters indicate a statistical different of means in the same column $(p<0.05)$.

\subsection{Cluster Analysis}

A hierarchical cluster analysis and constellation plot were performed to identity analogies of the effects of by-products on the properties of the bread (Figure 4). The constellation plot consisted of four clusters. Group A included one cluster (C1) containing only the wheat control bread, and group B included three clusters: C2 (gluten-free control bread), C3, and C4 (gluten-free bread containing different by-products). The C3 cluster contained the highest counts of similar bread. The similarity between DTP, DPP, DPPP, and DPPSP at the additive levels of $5 \%$ and $7.5 \%$ was observed in the $\mathrm{C} 3$ cluster and the gluten-free bread with the addition of DOP, DAP, and DPPPS at the $2.5 \%$ additive level in the $\mathrm{C} 4$ cluster. The wheat control bread and gluten-free control bread differed highly from those with all samples containing by-products. The wheat control bread was characterized by higher values of Vsp, average size, perimeter, $\mathrm{H}_{\mathrm{m}}, \mathrm{h}, \mathrm{Tx}$, and $\mathrm{R}_{\mathrm{CO} 2}$, and the control gluten-free bread was characterized by a long time at the maximum height of dough $\mathrm{T}_{1}$, a high value of $\mathrm{V}_{1 \mathrm{CO} 2}$, and a low value of $\mathrm{Vs}$, average size, $\mathrm{H}_{\mathrm{m}}$, and $\mathrm{R}_{\mathrm{CO} 2}$ (Figure 5) 


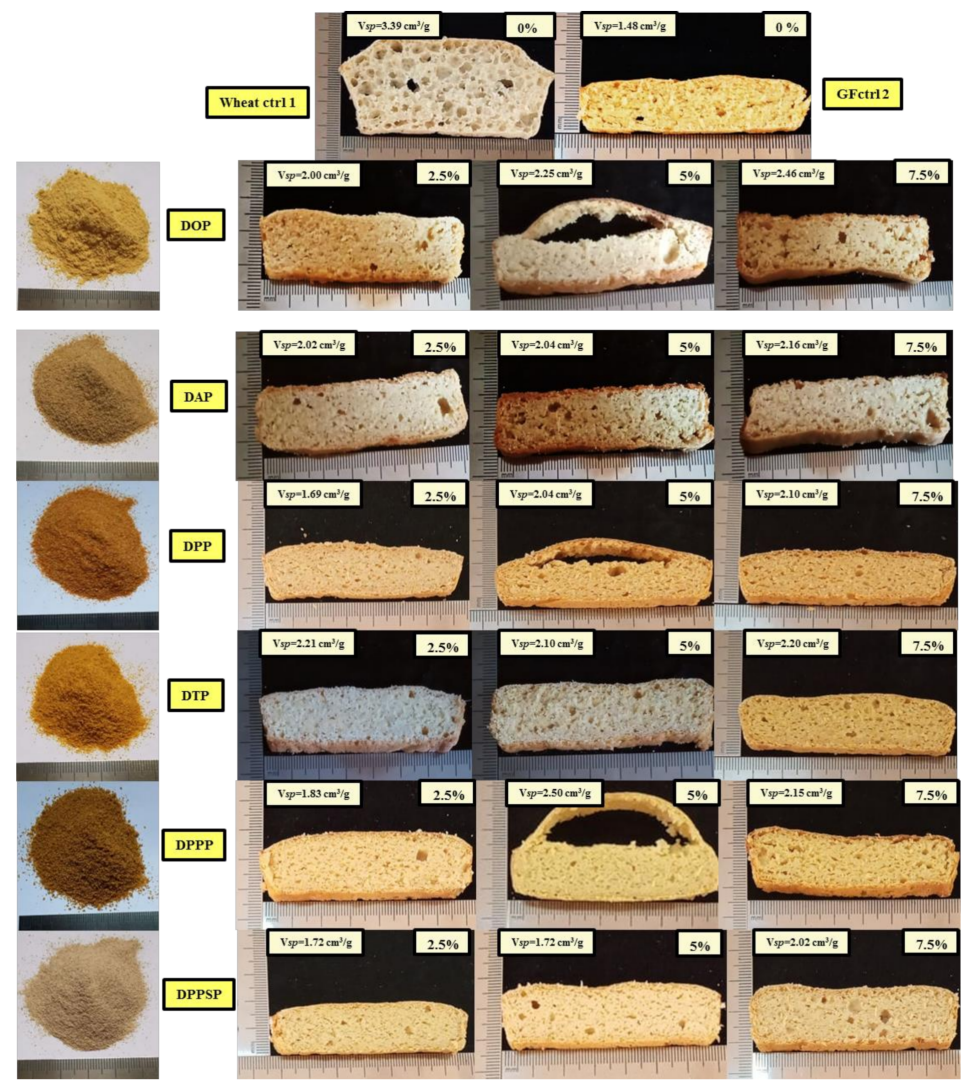

Figure 3. Crumb appearance of wheat bread and gluten-free bread with and without added byproducts. DOP: dried orange pomace; DAP: dried apple pomace; DTP: dried tomato peel; DPP: dried pepper peel; DPPP: dried prickly pear peel; DPPSP: dried prickly pear seed peel; CTRL: control; GF: gluten-free; Vsp: specific volume.

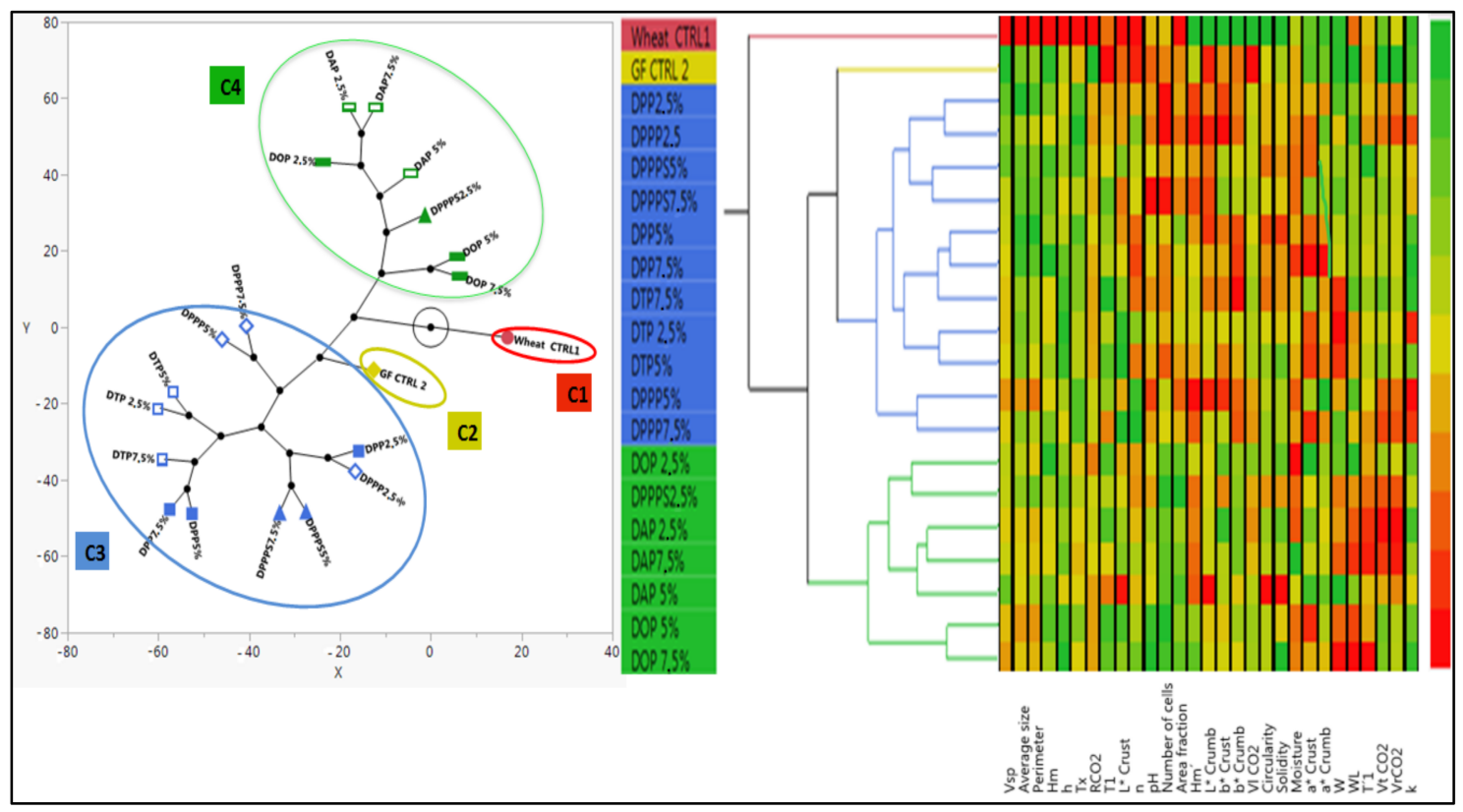

Figure 4. Constellation plot and hierarchical clustering of the investigated wheat and gluten-free bread samples based on the Ward method (level increase: orange, level decrease: green). DOP: dried orange pomace; DAP: dried apple pomace; DTP: dried tomato peel; DPP: dried pepper peel; DPPP: dried prickly pear peel; DPPSP: dried prickly pear seed peel; CTRL: control; GF: gluten-free. 


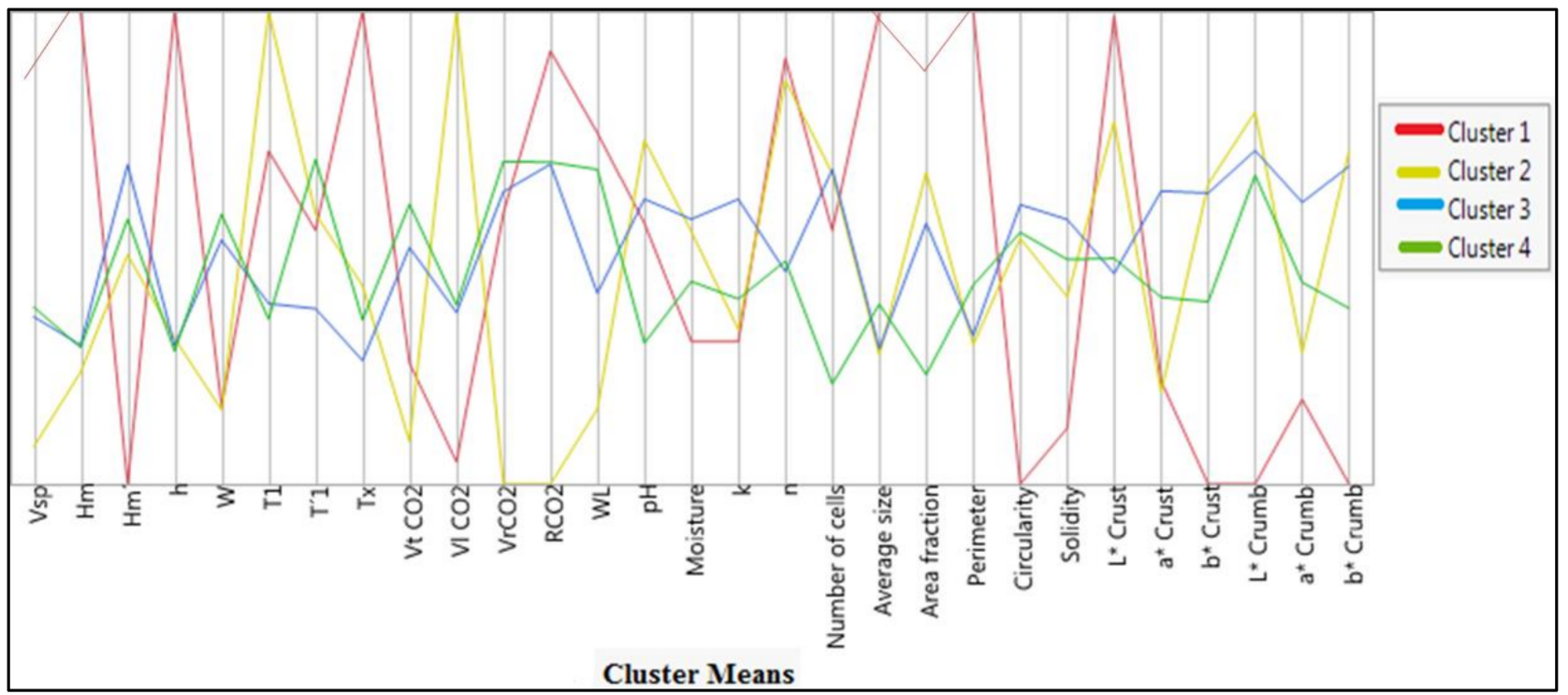

Figure 5. Cluster standard deviations (Cluster 1: wheat control; Cluster 2: gluten-free control; Cluster 3: DOP (2.5\%, 5\%, $7.5 \%)$, DAP $(2.5 \%, 5 \%, 7.5 \%)$, and DPPSP $2.5 \%$; Cluster 4 : DPP $(2.5 \%, 5 \%, 7.5 \%)$, DTP $(2.5 \%, 5 \%, 7.5 \%)$, DPPP $(2.5 \%, 5 \%$, $7.5 \%)$, and DPPSP $(5 \%, 7.5 \%))$.

3.6. Multivariate Analysis of the Rheofermentometer and Rheological Parameters of Dough and Bread Quality

Figure 6a presents the correlation circle obtained from the principal component analysis on the rheofermentometer and the rheological parameters of dough and bread qualities measured in wheat and gluten-free samples. The first and second principal components justified $49.3 \%$ of the variability. Variables with high eigenvectors on principal component 1 were $\mathrm{Tx}, \mathrm{H}_{\mathrm{m}}$, average size, perimeter, $\mathrm{h}, \mathrm{Vsp}, \mathrm{H}_{\mathrm{m}}^{\prime}$, and $\mathrm{L}^{*}$ crumb (Figure 6a). On PC1, Tx, $\mathrm{H}_{\mathrm{m}}$, average size, perimeter, $\mathrm{h}$, and Vsp were negatively correlated with $\mathrm{H}_{\mathrm{m}}^{\prime}$ and highly significant $(p<0.001)$ and positive correlations were noted between $\mathrm{H}_{\mathrm{m}}$ and $\mathrm{h}(\mathrm{r}=0.94)$, followed by the Tx and $H_{m}$ pairs $(r=0.89)$, Tx and $h(r=0.89)$ and $H_{m}$ and $V s p(r=0.81)$. Variables with high eigenvectors on principal component 2 were $\mathrm{W}, \mathrm{WL}, \mathrm{L}^{*}$ crust, $\mathrm{T}_{1}, \mathrm{pH}$, and $\mathrm{H} \%$. Negative correlations were observed between variables $W$ and $W L$ with $L^{*}$ crust, $\mathrm{T}_{1}$, and $\mathrm{pH}$. Highly significant $(p=0.001)$ and negative correlations were found between $\mathrm{pH}$ and $\mathrm{WL}(\mathrm{r}=-0.67), \mathrm{T}_{1}$ and $\%(\mathrm{r}=-0.62)$, and $\mathrm{T}_{1}$ and $\mathrm{W}(\mathrm{r}=-0.67)$. A scatter plot for bread (wheat and gluten-free bread) is shown in Figure 6b. Principal component analysis confirmed the hierarchical results of the cluster analysis, in which the wheat control bread and the gluten-free control bread were distinguished from gluten-free bread containing by-products. The wheat control bread showed higher $\mathrm{Tx}, \mathrm{H}_{\mathrm{m}}$, average size, and $\mathrm{h}$; glutenfree control bread showed higher $\mathrm{T}_{1}, \mathrm{pH}$, and $\mathrm{V}_{1 \mathrm{CO} 2}$; gluten-free bread prepared with DOP and DAP (all percentage) and DPPPS at $2.5 \%$ presented higher $\mathrm{W}, \mathrm{T}^{\prime}{ }_{1}, \mathrm{Vr}$, and $\mathrm{CO}_{2}$; and gluten-free bread containing DPP, DTP, DPPP, and DPPPS at 5 and 7.5\% showed higher $\mathrm{H}_{\mathrm{m}}^{\prime}, \mathrm{K}$, circularity, solidity, $a^{*}$ crumb, and $a^{*}$ crust (Figure 5). 


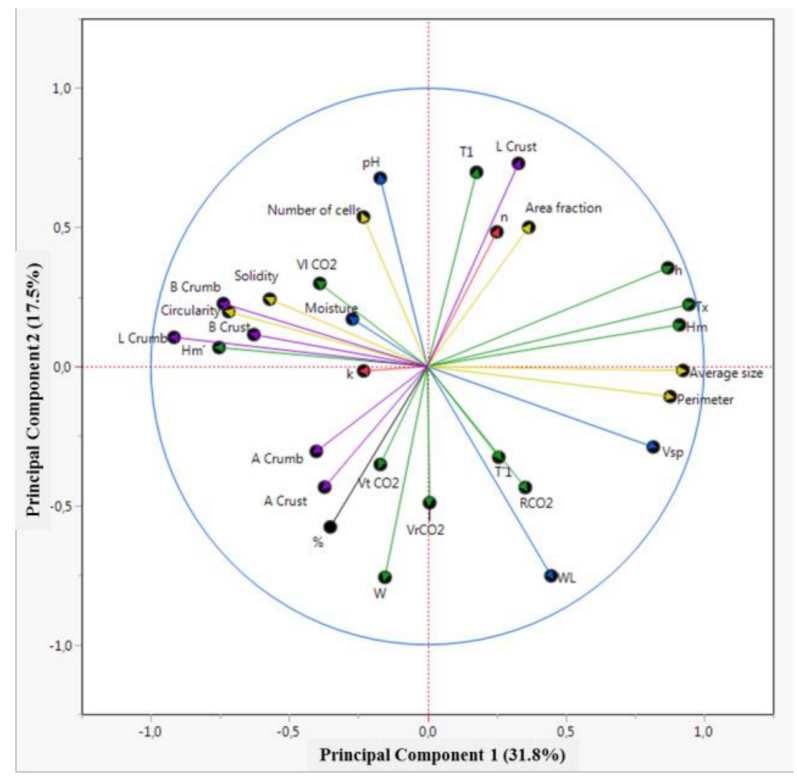

(a)

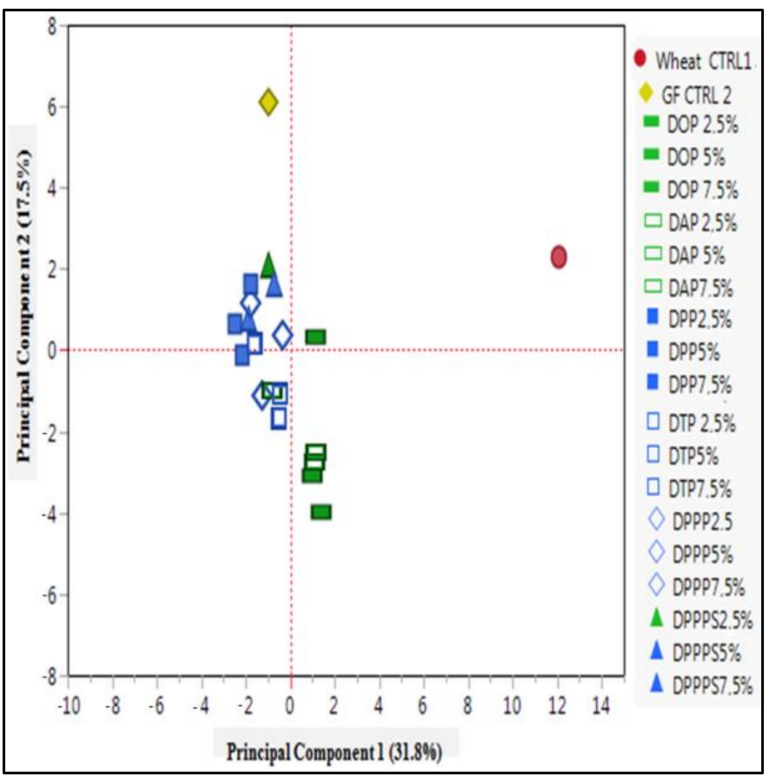

(b)

Figure 6. Multiple factor analysis correlating the percentage of by-products, dough rheological properties, and bread properties. (a) Map of parentage of by-products (in black), rheofermentometer parameters (in green) and rheological parameters of dough (in red), bread qualities (in blue), crumb structure of bread (in yellow), and crust and crumb colors (in purple). (b) Map of the distribution of the 20 types of bread.

\section{Conclusions}

Gluten-free bread based on the corn/chickpea formula was developed by adding different types of by-products (pomace of orange and apple; peels of tomato, pepper, and prickly pear; and prickly pear seeds). The rheology of the dough was measured and the properties of bread were evaluated. It was concluded that orange pomace, apple pomace, and peel of prickly pear seeds at $2.5 \% w / w$ induced the same effect on gluten-free bread. Pepper, tomato, prickly pear, and prickly pear seed peels with $5 \%$ and $7.5 \%$ addition had the same effect on gluten-free bread. Overall, all by-products increased $V s p, H_{m}, H_{m}^{\prime}$, $\mathrm{V}_{\mathrm{tCO} 2}, \mathrm{R}_{\mathrm{CO} 2}, \mathrm{WL}$, and circularity, and decreased $\mathrm{T}_{1}, \mathrm{~T}_{\mathrm{x}}, \mathrm{n}$, area fraction, $L^{*}$ crust, and $L^{*}$ crumb as compared to control gluten-free bread. The addition of prickly pear peel at a $5 \%$ addition level can result in bread with good characteristics. These by-products could be used as economical and inexpensive improvers for gluten-free bread.

Author Contributions: This study was designed by F.D. and M.N.Z. The analysis was done by F.D. and the manuscript was written by F.D. and H.B. and corrected by R.R., A.B., and W.T. All authors have read and agreed to the published version of the manuscript.

Funding: This research was funded by La Direction Générale de la Recherche Scientifique et du Développement Technologique (DGRSDT).

Institutional Review Board Statement: Not applicable.

Informed Consent Statement: Not applicable.

Data Availability Statement: The data presented in this study are available on request from the corresponding author R.R.

Acknowledgments: F. Djeghim acknowledges the Institut de la Nutrition, de l'Alimentation et des Technologies Agro-Alimentaires (INATAA), Algeria, the University of Life Sciences in Lublin, Poland, and the Centre de Recherche en Biotechnologie, Constantine, Algeria.

Conflicts of Interest: The authors have no conflict of interest to declare. 


\section{References}

1. El Khoury, D.; Balfour-Ducharme, S.; Joye, I.J. A review on the gluten-free diet: Technological and nutritional challenges. Nutrients 2018, 10, 1410. [CrossRef] [PubMed]

2. Naqash, F.; Gani, A.; Gani, A.; Masoodi, F. Gluten-free baking: Combating the challenges-A review. Trends Food Sci. Technol. 2017, 66, 98-107. [CrossRef]

3. Melini, F.; Melini, V.; Luziatelli, F.; Ruzzi, M. Current and forward-looking approaches to technological and nutritional improvements of gluten-free bread with legume flours: A critical review. Compr. Rev. Food Sci. Food Saf. 2017, 16, 1101-1122. [CrossRef] [PubMed]

4. Hager, A.-S.; Wolter, A.; Czerny, M.; Bez, J.; Zannini, E.; Arendt, E.K.; Czerny, M. Investigation of product quality, sensory profile and ultrastructure of breads made from a range of commercial gluten-free flours compared to their wheat counterparts. Eur. Food Res. Technol. 2012, 235, 333-344. [CrossRef]

5. Kurek, M.; Wyrwisz, J. The application of dietary fiber in bread products. J. Food Process. Technol. 2015, 6, 447-450. [CrossRef]

6. Bourekoua, H.; Gawlik-Dziki, U.; Różyło, R.; Zidoune, M.N.; Dziki, D. Acerola fruit as a natural antioxidant ingredient for gluten-free bread: An approach to improve bread quality. Food Sci. Technol. Int. 2020, 27, 13-21. [CrossRef]

7. Matos, M.E.; Rosell, C.M. Understanding gluten-free dough for reaching breads with physical quality and nutritional balance. J. Sci. Food Agric. 2015, 95, 653-661. [CrossRef] [PubMed]

8. Salehi, F. Improvement of gluten-free bread and cake properties using natural hydrocolloids: A review. Food Sci. Nutr. 2019, 7, 3391-3402. [CrossRef] [PubMed]

9. Bourekoua, H.; Różyło, R.; Benatallah, L.; Wójtowicz, A.; Łysiak, G.; Zidoune, M.N.; Sujak, A. Characteristics of gluten-free bread: Quality improvement by the addition of starches/hydrocolloids and their combinations using a definitive screening design. Eur. Food Res. Technol. 2017, 244, 345-354. [CrossRef]

10. Collar, C. Gluten-free dough-based foods and technologies. In Sorghum and Millets; Elsevier: Amsterdam, The Netherlands, 2019; pp. 331-354. [CrossRef]

11. O'Shea, N.; Arendt, E.; Gallagher, E. State of the art in gluten-free research. J. Food Sci. 2014, 79, R1067-R1076. [CrossRef]

12. Roman, L.; Belorio, M.; Gomez, M. Gluten-Free breads: The gap between research and commercial reality. Compr. Rev. Food Sci. Food Saf. 2019, 18, 690-702. [CrossRef] [PubMed]

13. Gómez, M.; Martinez, M.M. Fruit and vegetable by-products as novel ingredients to improve the nutritional quality of baked goods. Crit. Rev. Food Sci. Nutr. 2018, 58, 2119-2135. [CrossRef] [PubMed]

14. Bedrníček, J.; Jirotková, D.; Kadlec, J.; Laknerová, I.; Vrchotová, N.; Tř́íska, J.; Samková, E.; Smetana, P. Thermal stability and bioavailability of bioactive compounds after baking of bread enriched with different onion by-products. Food Chem. 2020, 319, 126562. [CrossRef] [PubMed]

15. Kumar, H.; Bhardwaj, K.; Sharma, R.; Nepovimova, E.; Kuča, K.; Dhanjal, D.S.; Verma, R.; Bhardwaj, P.; Sharma, S.; Kumar, D. Fruit and vegetable peels: Utilization of high value horticultural waste in novel industrial applications. Molecules 2020, 25, 2812. [CrossRef] [PubMed]

16. Patel, S.N.; Sharma, M.; Lata, K.; Singh, U.; Kumar, V.; Sangwan, R.S.; Singh, S.P. Improved operational stability of d-psicose 3-epimerase by a novel protein engineering strategy, and d-psicose production from fruit and vegetable residues. Bioresour. Technol. 2016, 216, 121-127. [CrossRef]

17. Pathak, P. Medicinal Properties of Fruit and Vegetable Peels. Adv. Bioeng. 2020, 115-128. [CrossRef]

18. Anwar, M.; Sallam, E. Utilization of prickly pear peels to improve quality of pan bread. Arab J. Nucl. Sci. Appl. 2016, 49, 151-163.

19. Coman, V.; Teleky, B.-E.; Mitrea, L.; Martău, G.A.; Szabo, K.; Călinoiu, L.-F.; Vodnar, D.C. Bioactive potential of fruit and vegetable wastes. Adv. Food Nutr. Res. 2020, 91, 157-225. [CrossRef]

20. Salim, N.; Abdelwaheb, C.; Rabah, C.; Ahcene, B. Chemical composition of Opuntia ficus-indica (L.) fruit. Afr. J. Biotechnol. 2009, $8,1623-1624$.

21. Babiker, W.A.; Sulieman, A.M.E.; Elhardallou, S.B.; Khalifa, E. Physicochemical properties of wheat bread supplemented with orange peel by-products. Int. J. Food Sci. Nutr. 2013, 2, 1-4. [CrossRef]

22. Mironeasa, S.; Mironeasa, C. Dough bread from refined wheat flour partially replaced by grape peels: Optimizing the rheological properties. J. Food Process. Eng. 2019, 42, e13207. [CrossRef]

23. Pathak, D.; Majumdar, J.; Raychaudhuri, U.; Chakraborty, R. Characterization of physicochemical properties in whole wheat bread after incorporation of ripe mango peel. J. Food Meas. Charact. 2016, 10, 554-561. [CrossRef]

24. AOAC. Official Methods of Analysis; Association of Official Analytical Chemists: Rockville, MD, USA, 2005.

25. Henneberg, W.; Stohmann, F. Beiträge zur Begründung einer Rationellen Fütterung der Wiederkäuer; Braunschweig: Schwetschke, Germany, 1864; Volume 2.

26. Abid, M.; Cheikhrouhou, S.; Renard, C.M.; Bureau, S.; Cuvelier, G.; Attia, H.; Ayadi, M. Characterization of pectins extracted from pomegranate peel and their gelling properties. Food Chem. 2017, 215, 318-325. [CrossRef] [PubMed]

27. Doukani, K.; Tabak, S. Profil Physicochimique du fruit" Lendj"(Arbutus unedo L.). Nat. Technol. 2015, 51, 53-66.

28. Liew, S.Q.; Chin, N.L.; Yusof, Y.A. Extraction and characterization of pectin from passion fruit peels. Agric. Agric. Sci. Procedia 2014, 2, 231-236. [CrossRef]

29. Torralbo, D.; Batista, K.; Di-Medeiros, M.; Fernandes, K. Extraction and partial characterization of Solanum lycocarpum pectin. Food Hydrocoll. 2012, 27, 378-383. [CrossRef] 
30. McConnell, A.; Eastwood, M.; Mitchell, W. Physical characteristics of vegetable foodstuffs that could influence bowel function. J. Sci. Food Agric. 1974, 25, 1457-1464. [CrossRef]

31. Ang, J.F. Water retention capacity and viscosity effect of powdered cellulose. J. Food Sci. 1991, 56, 1682-1684. [CrossRef]

32. Rabetafika, H.N.; Bchir, B.; Aguedo, M.; Paquot, M.; Blecker, C. Effects of processing on the compositions and physicochemical properties of fibre concentrate from cooked fruit pomaces. Food Bioproc. Technol. 2014, 7, 749-760. [CrossRef]

33. Gómez, M.; Talegón, M.; De La Hera, E. Influence of mixing on quality of gluten-free bread. J. Food Qual. 2013, 36, 139-145. [CrossRef]

34. Martínez, M.M.; Díaz, Á.; Gómez, M. Effect of different microstructural features of soluble and insoluble fibres on gluten-free dough rheology and bread-making. J. Food Eng. 2014, 142, 49-56. [CrossRef]

35. Ronda, F.; Pérez-Quirce, S.; Villanueva, M. Rheological properties of gluten-free bread doughs: Relationship with bread quality. In Advances in Food Rheology and Its Applications; Elsevier: Amsterdam, The Netherlands, 2017; pp. 297-334. [CrossRef]

36. Altuna, L.; Ribotta, P.D.; Tadini, C.C. Effect of a combination of enzymes on dough rheology and physical and sensory properties of bread enriched with resistant starch. LWT Food Sci. Technol. 2015, 64, 867-873. [CrossRef]

37. Dai, S.; Qi, F.; Tanner, R. Interpreting shear creep data for bread dough using a damage function model. Appl. Rheol. 2011, 21. [CrossRef]

38. Hicks, C.I.; See, H. The rheological characterisation of bread dough using capillary rheometry. Rheol. Acta 2010, 49, 719-732. [CrossRef]

39. Tanner, R.I.; Qi, F.; Dai, S.-C. Bread dough rheology and recoil: I. Rheology. J. Non-Newton. Fluid Mech. 2008, 148, 33-40. [CrossRef]

40. Witczak, M.; Korus, J.; Ziobro, R.; Juszczak, L. The effects of maltodextrins on gluten-free dough and quality of bread. J. Food Eng. 2010, 96, 258-265. [CrossRef]

41. Sabanis, D.; Lebesi, D.; Tzia, C. Effect of dietary fibre enrichment on selected properties of gluten-free bread. LWT Food Sci. Technol. 2009, 42, 1380-1389. [CrossRef]

42. Chen, H.; Rubenthaler, G.; Leung, H.; Baranowski, J. Chemical, physical, and baking properties of apple fiber compared with wheat and oat bran. Cereal Chem. 1988, 65, 244-247.

43. Keskin, S.O.; Sumnu, G.; Sahin, S. Bread baking in halogen lamp-microwave combination oven. Food Res. Int. 2004, 37, 489-495. [CrossRef]

44. AACC. American Association of Cereal Chemists. Approved Methods of the AACC; The Association: St Paul, MN, USA, 2000.

45. ICC. Standard Methods of the International Association for Cereal Science and Technology; International Association for Cereal Chemistry: Vienna, Austria, 1996.

46. Majzoobi, M.; Poor, Z.V.; Jamalian, J.; Farahnaky, A. Improvement of the quality of gluten-free sponge cake using different levels and particle sizes of carrot pomace powder. Int. J. Food Sci. Technol. 2016, 51, 1369-1377. [CrossRef]

47. Majzoobi, M.; Vosooghi Poor, Z.; Mesbahi, G.; Jamalian, J.; Farahnaky, A. Effects of carrot pomace powder and a mixture of pectin and xanthan on the quality of gluten-free batter and cakes. J. Texture Stud. 2017, 48, 616-623. [CrossRef] [PubMed]

48. He, X.; Pei, Q.; Xu, T.; Zhang, X. Smartphone-based tape sensors for multiplexed rapid urinalysis. Sens. Actuators B Chem. 2020, 304, 127415. [CrossRef]

49. Chen, C.; Ren, M. The significance of license plate location based on Lab color space. In Proceedings of the 2nd International Conference on Information, Electronics and Computer, Wuhan, China, 7-9 March 2014; Atlantis Press: Paris, France, 2014.

50. Skinner, R.C.; Gigliotti, J.C.; Ku, K.-M.; Tou, J.C. A comprehensive analysis of the composition, health benefits, and safety of apple pomace. Nutr. Rev. 2018, 76, 893-909. [CrossRef]

51. Ocen, D.; Xu, X. Effect of citrus orange (Citrus sinensis) by-product dietary fiber preparations on the quality characteristics of frozen dough bread. Am. J. Food Technol. 2013, 8, 43-53. [CrossRef]

52. Bchir, B.; Rabetafika, H.N.; Paquot, M.; Blecker, C. Effect of pear, apple and date fibres from cooked fruit by-products on dough performance and bread quality. Food Bioprocess Technol. 2014, 7, 1114-1127. [CrossRef]

53. Yilmaz, E.; Emir, D.D. Compositional and functional characterisation of poppy seed (Papaver somniferum L.) press cake meals. Qual. Assur. Saf. Crop Foods 2017, 9, 141-151. [CrossRef]

54. Hosseini, S.S.; Khodaiyan, F.; Kazemi, M.; Najari, Z. Optimization and characterization of pectin extracted from sour orange peel by ultrasound assisted method. Int. J. Biol. Macromol. 2019, 125, 621-629. [CrossRef]

55. Boubaker, M.; Omri, A.E.; Blecker, C.; Bouzouita, N. Fibre concentrate from artichoke (Cynara scolymus L.) stem by-products: Characterization and application as a bakery product ingredient. Food Sci. Technol. Int. 2016, 22, 759-768. [CrossRef]

56. O'shea, N.; Rößle, C.; Arendt, E.; Gallagher, E. Modelling the effects of orange pomace using response surface design for gluten-free bread baking. Food Chem. 2015, 166, 223-230. [CrossRef] [PubMed]

57. Grigelmo-Miguel, N.; Martín-Belloso, O. Characterization of dietary fiber from orange juice extraction. Food Res. Int. 1998, 31, 355-361. [CrossRef]

58. Wang, X.; Chen, Q.; Lü, X. Pectin extracted from apple pomace and citrus peel by subcritical water. Food Hydrocoll. 2014, 38, 129-137. [CrossRef]

59. Sundarraj, A.A.; Ranganathan, T.V. A review-Pectin from Agro and industrial waste. Int. J. Appl. Environ. Sci. 2017, 12, 1777-1801.

60. Dalal, N.; Neeraj, V.B.; Dhakar, U. Potential of fruit and vegetable waste as a source of pectin. IJCS 2020, 8, 3085-3090. [CrossRef]

61. Verheyen, C.; Jekle, M.; Becker, T. Effects of Saccharomyces cerevisiae on the structural kinetics of wheat dough during fermentation. LWT Food Sci. Technol. 2014, 58, 194-202. [CrossRef] 
62. Sudha, M. Apple pomace (by-product of fruit juice industry) as a flour fortification strategy. In Flour and Breads and Their Fortification in Health and Disease Prevention; Elsevier: Amsterdam, The Netherlands, 2011; pp. 395-405. [CrossRef]

63. Gowe, C. Review on potential use of fruit and vegetables by-products as a valuable source of natural food additives. Food Sci. Qual. Manag. 2015, 45, 47-61.

64. Chiocchetti, G.D.M.E.; Fernandes, E.A.D.N.; Bacchi, M.A.; Pazim, R.A.; Sarriés, S.R.V.; Tome, T.M. Mineral composition of fruit by-products evaluated by neutron activation analysis. J. Radioanal. Nucl. Chem. 2013, 297, 399-404. [CrossRef]

65. Walker, G.M.; Stewart, G.G. Saccharomyces cerevisiae in the production of fermented beverages. Beverages 2016, 2, 30. [CrossRef]

66. Struyf, N.; Van der Maelen, E.; Hemdane, S.; Verspreet, J.; Verstrepen, K.J.; Courtin, C.M. Bread dough and baker's yeast: An uplifting synergy. Compr. Rev. Food Sci. Food Saf. 2017, 16, 850-867. [CrossRef]

67. Zhu, F.; Sakulnak, R.; Wang, S. Effect of black tea on antioxidant, textural, and sensory properties of Chinese steamed bread. Food Chem. 2016, 194, 1217-1223. [CrossRef]

68. Cheremisinoff, N.P. Practical Fluid Mechanics for Engineers \& Scientists; CRC Press: Boca Raton, FL, USA, 1990.

69. Krokida, M.; Maroulis, Z.; Saravacos, G. Rheological properties of fluid fruit and vegetable puree products: Compilation of literature data. Int. J. Food Prop. 2001, 4, 179-200. [CrossRef]

70. Ramsey, M. Rheology, Viscosity, and Fluid Types. Pract. Wellbore Hydraul. Hole Clean. 2019, 217-237.

71. Padmanabhan, M.; Bhattacharya, M. Flow behavior and exit pressures of corn meal under high-shear-high-temperature extrusion conditions using a slit diea. J. Rheol. 1991, 35, 315-343. [CrossRef]

72. Fraiha, M.; Biagi, J.D.; Ferraz, A.C.d.O. Rheological behavior of corn and soy mix as feed ingredients. Food Sci. Technol. 2011, 31, 129-134. [CrossRef]

73. Drozdek, K.D.; Faller, J.F. Use of a dual orifice die for on-line extruder measurement of flow behavior index in starchy foods. J. Food Eng. 2002, 55, 79-88. [CrossRef]

74. Milde, L.B.; Ramallo, L.A.; Puppo, M.C. Gluten-free bread based on tapioca starch: Texture and sensory studies. Food Bioproc. Technol. 2012, 5, 888-896. [CrossRef]

75. Parra, A.F.R.; Ribotta, P.D.; Ferrero, C. Apple pomace in gluten-free formulations: Effect on rheology and product quality. Int. J. Food Sci. Technol. 2015, 50, 682-690. [CrossRef]

76. O'shea, N.; Ktenioudaki, A.; Smyth, T.; McLoughlin, P.; Doran, L.; Auty, M.; Arendt, E.; Gallagher, E. Physicochemical assessment of two fruit by-products as functional ingredients: Apple and orange pomace. J. Food Eng. 2015, 153, 89-95. [CrossRef]

77. Arslan, M.; Rakha, A.; Khan, M.R.; Zou, X. Complementing the dietary fiber and antioxidant potential of gluten free bread with guava pulp powder. J. Food Meas. Charact. 2017, 11, 1959-1968. [CrossRef]

78. Singh, J.P.; Kaur, A.; Singh, N. Development of eggless gluten-free rice muffins utilizing black carrot dietary fibre concentrate and xanthan gum. J. Food Sci. Technol. 2016, 53, 1269-1278. [CrossRef]

79. Türker, B.; Savlak, N.; Kaşıkc1, M.B. Effect of green banana peel flour substitution on physical characteristics of gluten-free cakes. Curr. Res. Nutr. Food Sci. J. 2016, 4, 197-204. [CrossRef]

80. Khosravi, F.; Iranmanesh, B.; Olia, S.S.S.J. Determination of Organic Acids in Fruit juices by UPLC. Int. J. Life Sci. 2015, 9, 41-44. [CrossRef]

81. Tezcan, F.; Uzaşçı, S.; Uyar, G.; Öztekin, N.; Erim, F.B. Determination of amino acids in pomegranate juices and fingerprint for adulteration with apple juices. Food Chem. 2013, 141, 1187-1191. [CrossRef] [PubMed]

82. Gómez-Ariza, J.; Villegas-Portero, M.; Bernal-Daza, V. Characterization and analysis of amino acids in orange juice by HPLCMS/MS for authenticity assessment. Anal. Chim. Acta 2005, 540, 221-230. [CrossRef]

83. Martins, Z.; Pinho, O.; Ferreira, I. Fortification of Wheat Bread with Agroindustry By-Products: Statistical Methods for Sensory Preference Evaluation and Correlation with Color and Crumb Structure. J. Food Sci. 2017, 82, 2183-2191. [CrossRef] [PubMed]

84. Capriles, V.D.; Arêas, J.A.G. Novel approaches in gluten-free breadmaking: Interface between food science, nutrition, and health Compr. Rev. Food Sci. Food Saf. 2014, 13, 871-890. [CrossRef]

85. Jafari, M.; Koocheki, A.; Milani, E. Functional effects of xanthan gum on quality attributes and microstructure of extruded sorghum-wheat composite dough and bread. LWT Food. Sci. Technol. 2018, 89, 551-558. [CrossRef]

86. Goriewa-Duba, K.; Duba, A.; Wachowska, U.; Wiwart, M. An evaluation of the variation in the morphometric parameters of grain of six Triticum species with the use of digital image analysis. Agronomy 2018, 8, 296. [CrossRef]

87. Alba, K.; Rizou, T.; Paraskevopoulou, A.; Campbell, G.M.; Kontogiorgos, V. Effects of blackcurrant fibre on dough physical properties and bread quality characteristics. Food Biophys. 2020, 313-322. [CrossRef] 